\title{
Evolution of the Iberian Massif as deduced from its crustal thickness and geometry of a mid-crustal (Conrad) discontinuity
} \author{
Ramón Carbonell ${ }^{2}$ \\ ${ }^{1}$ Geology Department, Salamanca University, Salamanca 37008, Spain \\ ${ }^{2}$ Geosciences Barcelona, CSIC, Lluis Solé i Sabaris, Barcelona 08028, Spain \\ ${ }^{3}$ Geodynamics Department, Granada University, Granada 18071, Spain \\ ${ }^{4}$ Lithica SCCL, Santa Coloma de Farners, Girona 17430, Spain \\ ${ }^{5}$ Department of Earth Sciences, Uppsala University, Uppsala 75236, Sweden
}

Puy Ayarza $^{1}$, José Ramón Martínez Catalán ${ }^{1}$, Ana Martínez García ${ }^{2}$, Juan Alcalde ${ }^{2}$, Juvenal Andrés ${ }^{1,2}$, José Fernando Simancas ${ }^{3}$, Immaculada Palomeras ${ }^{1}$, David Martî ${ }^{2,4}$, Irene DeFelipe ${ }^{2}$, Chris Juhlin ${ }^{5}$, and

Correspondence: Puy Ayarza (puy@usal.es)

Received: 11 September 2020 - Discussion started: 7 October 2020

Revised: 17 May 2021 - Accepted: 27 May 2021 - Published: 6 July 2021

\begin{abstract}
Normal incidence seismic data provide the best images of the crust and lithosphere. When properly designed and continuous, these sections greatly contribute to understanding the geometry of orogens and, along with surface geology, unraveling their evolution. In this paper we present the most complete transect, to date, of the Iberian Massif, the westernmost exposure of the European Variscides. Despite the heterogeneity of the dataset, acquired during the last 30 years, the images resulting from reprocessing the data with a homogeneous workflow allow us to clearly define the crustal thickness and its internal architecture. The Iberian Massif crust, formed by the amalgamation of continental pieces belonging to Gondwana and Laurussia (Avalonian margin), is well structured in the upper and lower crust. A conspicuous mid-crustal discontinuity is clearly defined by the top of the reflective lower crust and by the asymptotic geometry of reflections that merge into it, suggesting that it has often acted as a detachment. The geometry and position of this discontinuity can give us insights into the evolution of the orogen (i.e., of the magnitude of compression and the effects and extent of later-Variscan gravitational collapse). Moreover, the limited thickness of the lower crust below, in central and northwestern Iberia, might have constrained the response of the Iberian microplate to Alpine shortening. Here, this discontinuity, featuring a $V p$ ( $P$-wave velocity) increase, is observed as an orogen-scale boundary with charac-
\end{abstract}

teristics compatible with those of the globally debated Conrad discontinuity.

\section{Introduction}

In the last 35 years, controlled source seismic data have greatly contributed to the understanding of the European Variscides. National research programs like DEKORP (Bortfeld, 1985; DEKORP Research Group, 1987; Franke et al., 1990; Oncken, 1998), BIRPS, and ECORS (BIRPS and ECORS, 1986) have sampled this orogen, providing a detailed picture of its lithospheric architecture. In the Iberian Massif, normal incidence (NI) seismic reflection profiles, which are often acquired with coincident wide-angle (WA) reflection/refraction seismic data, have allowed scientists to depict its crustal structure, infer its $\mathrm{P}$ - and S-wave velocity distribution, place constraints on its geodynamic evolution, visualize the accommodation pattern of shortening at different crustal levels, and, sometimes, deduce the effect of Alpine reactivation on this Paleozoic orogen.

In this regard, seismic datasets acquired in the Iberian Massif (DeFelipe et al., 2021) within the ESCIN (Ayarza et al., 1998, 2004; Pérez-Estaún et al., 1991; Pulgar et al., 1996), IBERSEIS (Flecha et al., 2009; Palomeras et al., 2009; Simancas et al., 2003), ALCUDIA (e.g., Ehsan et al., 2014, 2015; Martínez Poyatos et al., 2012), and CIMDEF 
projects (Andrés et al., 2019) have helped to identify several outstanding features, such as (i) clear differences in the intensity and geometry of reflectivity at upper and lower crustal levels; (ii) contrasting deformation patterns deduced from the good correlation between reflectivity and upper-crustal structures as, regardless of the many factors that trigger the concentration of deformation along narrow thrust zones (Butler and Mazzoli, 2006), the latter often follow lithological boundaries in the Iberian Massif (e.g., Alonso, 1987), thus being candidates to appear as outstanding reflections; and (iii) a very reflective and sometimes thick lower crust, even in areas where the upper crust is weakly deformed. In order to explain these features, decoupling of the upper and lower crust, eased by a mid-crustal detachment, has been invoked along large parts of the sampled area (Simancas et al., 2013). However, coupled crustal deformation has been inferred in northwestern Iberia, where large crustal thickening took place. Furthermore, no inference has been made on how this detachment acted during later Alpine deformation in the central and northern Iberian Massif.

In this paper, we present a new composite seismic section of the Iberian Massif that integrates results of two new datasets: CIMDEF and ALCUDIA WA. CIMDEF fills the gap between areas previously unexplored, like central Iberia, thereby contributing to the provision of an almost complete transect. In addition, we include the north-south, ESCIN-2 seismic profile and new time-migrated sections of all datasets, although some of them are currently unmigrated (e.g., ESCIN-1). Even though the detailed interpretation of the upper-crustal reflectivity and its correlation with the surface geology does not significantly change, we revisit the deep reflectivity and redefine the extension and implications of a mid-crustal discontinuity that, in our view, exists below the entire Iberian Massif, affecting the two continents involved in the Variscan Orogeny and certainly playing a critical role in the decoupling between upper and lower crustal deformation. Finally, we infer the geometry and nature of this feature, discuss its tectonic significance and its role during the younger Alpine Orogeny, and relate it to the long-debated (e.g., Finlayson et al., 1984; Litak and Brown, 1989; Wever, 1989; Xiaobo and Tae Kyung, 2010) Conrad discontinuity (Conrad, 1925) of classic continental seismology.

\section{Geological setting}

The Iberian Massif represents the westernmost outcrop of the European Variscides, exposing an almost complete section of this Paleozoic orogen. It is divided into six zones (Fig. 1; Arenas et al., 1988; Farias et al., 1987; Julivert et al., 1972) from north to south and east to west: the Cantabrian (CZ), the West Asturian-Leonese (WALZ), the Galicia-Trásos-Montes (GTMZ), the Central Iberian (CIZ), the OssaMorena (OMZ), and the South Portuguese (SPZ). The CZ and the SPZ represent external zones, whereas the rest rep- resent the hinterland. The CZ, WALZ, and CIZ belong to the northern margin of the Paleozoic Gondwana. The GTMZ represents the remnants of a large nappe stack formed by pieces of the outermost Gondwana margin (i.e., a pulledapart peri-Gondwanan terrane and ophiolitic units derived from the Rheic oceanic realm separating them). The OMZ has been interpreted as a continental fragment that rifted and probably drifted away from Gondwana (Matte, 2001; Robardet, 2002), docking back later to the CIZ and giving rise to a suture (Azor et al., 1994; Gómez-Pugnaire et al., 2003; Simancas et al., 2001). Finally, the SPZ is also thought to be separated from the OMZ by the Rheic Ocean suture (Simancas et al., 2003) which was later overprinted by earlyCarboniferous extension (Azor et al., 2008) and by transpression (Pérez-Cáceres et al., 2015). In this context, the basement of the SPZ represents a fragment of Avalonia (Braid et al., 2011, 2012; Pereira et al., 2014; Rodrigues et al., 2015), and its affinity with the Rhenohercynian Zone in Germany (Franke, 2000; Franke et al., 1990) further supports this correlation.

From a tectonic point of view, the Iberian Massif shows evidence of pre-Variscan activity. The Cadomian Neoproterozoic event is characterized by continental arc magmatism, deformation, and metamorphism (Bandrés et al., 2004; Dallmeyer and Quesada, 1992; Ochsner, 1993). It developed above a previous non-outcropping continental crust and formed the basement above which the Ediacaran and Paleozoic sedimentation took place, favored by EdiacaranCambrian and Cambro-Ordovician rifting which developed a wide continental platform (Linnemann et al., 2008; SánchezGarcía et al., 2008, 2010). However, most of the outcropping tectonic features are the result of the Devonian and Carboniferous collision between Gondwana, some peri-Gondwanan terranes, and the Avalonian border of Laurentia, which resulted in the Variscan Orogen (Matte, 2001). The deformation associated with the latter was diachronous along the Iberian Massif. Next, we describe the most important tectonic and stratigraphic features of this part of the European Variscides, by tectonic zones and from north to south (in present coordinates).

\subsection{Cantabrian Zone (CZ)}

The CZ (Fig. 1) is an external zone located at the core of the Ibero-Armorican Arc (IAA; Dias and Ribeiro, 1995; Lotze, 1929; Matte and Ribeiro, 1975; Stille, 1924). It is a thinskinned thrust and fold belt with a transport direction towards the foreland to the east, and it is overprinted by the oroclinal folding, giving rise to the IAA (Alonso et al., 2009; Pérez-Estaún et al., 1988). Stratigraphically, it is characterized by a Precambrian sequence, outcropping at its western part and overlain by a Paleozoic stratigraphic succession that ranges from the Cambrian to a well-developed Carboniferous: pre-orogenic up to early Carboniferous and synorogenic in the upper Carboniferous (Sánchez de Posada et al., 1990; 


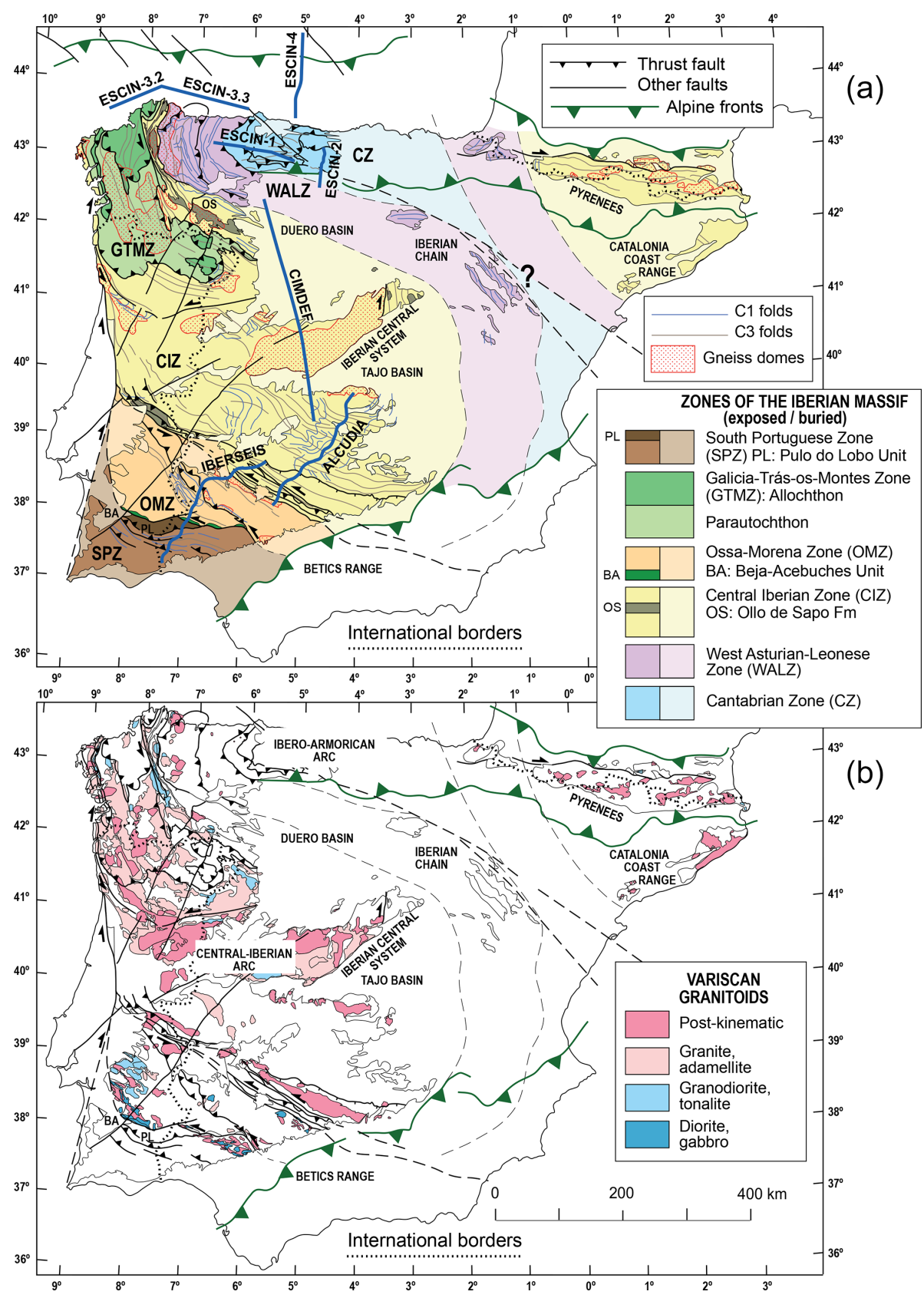

Figure 1. (a) Map of the Iberian Peninsula showing the outcrops of the Variscan basement and the subdivision of the Iberian Massif into zones. The main strike-slip shear zones, traces of Variscan folds, and gneiss domes are also included. Blue lines show the position of normal incidence seismic reflection profiles and the position of the CIMDEF transect. See the legend for abbreviations. (b) Map of the outcropping granitoids in the Iberian Peninsula showing the main structures.

Truyols et al., 1990). Scarce tholeiitic and alkaline magmatism is related to Cambro-Ordovician rifting (Corretgé and Suárez, 1990). No regional metamorphism accompanied deformation, indicating shallow crustal conditions. In this area, deformation began at $\sim 325-320 \mathrm{Ma}$, in the late Mississippian (Dallmeyer et al., 1997), and the emplacement of nappes that characterize the deformation and the formation of folds took place between the Westphalian B and the Stephanian
(313-300 Ma), in the upper Carboniferous (Pérez-Estaún et al., 1988). An extensional episode related to the end of the orogeny led to the formation of Permian basins (Martínez García, 1981). Later on, extension related to the opening of the Bay of Biscay triggered the development of deep Cretaceous basins (Quintana et al., 2015; Rat, 1988). Alpine tectonics uplifted the Pyrenean-Cantabrian range from the end of the Late Cretaceous to the Miocene (DeFelipe et al., 
2019; Teixell et al., 2018, and references therein), reactivating Variscan thrusts and Mesozoic normal faults (Gallastegui et al., 2016).

\subsection{West Asturias-Leonese Zone (WALZ)}

The WALZ lies to the west of the CZ (Fig. 1). Stratigraphically, it consists of a Neoproterozoic terrigenous sequence unconformably overlain by a Paleozoic platform succession that ranges from the Cambrian to the Lower Devonian (Pérez-Estaún et al., 1990), with the Neoproterozoic terrigenous sequence being much thicker in the WALZ than in the CZ. These sediments were actively deformed along three compressional $\left(C_{1}, C_{2}\right.$, and $\left.C_{3}\right)$ and two extensional $\left(E_{1}\right.$ and $\left.E_{2}\right)$ phases during the Variscan Orogeny (Martínez Catalán et al., 2014). Large east-vergent folds witness the $C_{1}$ related compression (360-340 Ma). These were later affected by east-vergent thrusts resulting from ongoing shortening (345-325 Ma). Crustal thickening followed by thermal relaxation led to synorogenic extension during $E_{1}(330-315 \mathrm{Ma})$. A last compressional episode $\left(C_{3}, 315-305 \mathrm{Ma}\right)$ produced upright folds associated with wrench shear zones while simultaneous extension $\left(E_{2}, 315-300 \mathrm{Ma}\right)$ continued, characterizing the latest stages of the orogeny in this area. Crustal melting triggered by compression and thickening $\left(C_{1}-C_{3}\right)$ led to extension $\left(E_{1}-E_{2}\right)$ and to the intrusion of granitoids in the western part of the WALZ. Thermal models show that the crust could have started to melt within $30 \mathrm{Myr}$ of the onset of crustal thickening, which is then constrained by the ages of Variscan granitoids (Alcock et al., 2009).

\subsection{The Central Iberian Zone (CIZ)}

The CIZ is the largest of the Iberian Massif zones. Curvature of magnetic anomalies and that of early $\left(C_{1}\right)$ Variscan folds depict the Central Iberian Arc (CIA; Martínez Catalán, 2011), partly explaining the width of this internal zone (Fig. 1). The stratigraphic sequence differs from north to south: Ordovician felsic metavolcanic, subvolcanic, and intrusives (Diez-Montes et al., 2010) represent the most ancient lithologies outcropping in the north, defining the "Ollo de Sapo" domain, whereas to the south, upper-Proterozoiclower-Cambrian metasediments outcrop (Díez Balda et al., 1995), defining the "Schist-Greywacke Complex" domain. The pre-orogenic sedimentary sequence continues to the Devonian, followed by a synorogenic Carboniferous sequence (Martínez Catalán et al., 2004; Robardet, 2002). This area represents a relatively stable Gondwana margin characterized by the early-Ordovician extension that opened the Rheic Ocean and allowed intrusion of the essentially felsic magmas of the Ollo de Sapo Fm (Díez Montes et al., 2010). The deformation phases described for the WALZ affected most of the $\mathrm{CIZ}$, although $C_{1}, C_{2}$, and $E_{1}$ are somewhat older, according to the propagation of deformation from the hinterland. Slight differences in the importance of phases can also be found to the center and south (Martínez Catalán et al., 2019), allowing the CIZ to be divided in two zones. In the northwest, intense recumbent $C_{1}$ folds and important $C_{2}$ thrusts related to the emplacement of the GTMZ occur. Outcropping rocks show epi- to catazonal metamorphism and ductile detachments. Gneiss domes of both $E_{1}$ and $E_{2}$ extensional phases exist, evidencing significant crustal thinning, and Variscan granitoids are abundant. To the south, $C_{1}$ folds are upright, $C_{2}$ deformation is limited to the southernmost part, and upright $C_{3}$ folds are the most important structures (Martínez Catalán et al., 2012; Martínez Poyatos, 2002). Metamorphism is generally weak and the amount of granitoids decreases, except in the Iberian Central System (ICS). Here extension postdates $C_{3}$ upright folding; thus, it is considered $E_{2}$. Alpine tectonics in the CIZ reactivated previous Variscan fractures and triggered the development of the Iberian Central System (ICS) mountain belt (de Vicente et al., 1996), allowing the products of syn- and post- $E_{2}$ crustal melting to outcrop in large areas.

\subsection{The Galicia-Trás-os-Montes Zone (GTMZ)}

The GTMZ is represented by five klippen that are remnants of the emplacement of a thick nappe stack on top of the CIZ. This includes, from bottom to top, a relatively distal part of the northern Gondwana margin (Parautochthon), the outermost edge of that margin (lower Allochthon), a few oceanic units of Cambro-Ordovician and Lower Devonian age (middle Allochthon), and a peri-Gondwanan terrane with magmatic evidence of Cambro-Ordovician rifting and a continental arc setting (upper Allochthon). Several units show high$\mathrm{P}$ metamorphism reflecting subduction of the ocean represented by the middle Allochthon and also involving the upper and lower ones (Arenas et al., 2007; Gómez Barreiro et al., 2007; Martínez Catalán et al., 2007; Sánchez Martínez et al., 2007). Ongoing subduction during most of the Devonian (400-365 Ma) built an accretionary wedge that was subsequently emplaced on top of the CIZ during the early Carboniferous $\left(C_{1}-C_{2}\right.$ events, $\left.360-340 \mathrm{Ma}\right)$.

\subsection{The Ossa-Morena Zone (OMZ)}

The boundary between the CIZ and the OMZ (the Badajoz Córdoba Shear Zone) has been largely interpreted as a suture (Gómez-Pugnaire et al., 2003; Simancas et al., 2001), although no true oceanic units have been identified. It includes amphibolites of oceanic affinity from the early Paleozoic, as well as eclogite relics.

In general, southwestern Iberia features outcrops from the upper Precambrian to the upper Carboniferous, with an angular unconformity at the lower Carboniferous. In the OMZ, the Serie Negra (Black Series) is a thick Neoproterozoic sequence that includes graphitic quartzites and schists and underwent Cadomian arc-related magmatism and regional metamorphism (Dallmeyer and Quesada, 1992; Ochsner, 1993; Quesada and Dallmeyer, 1994). The pre-orogenic Pa- 
leozoic sequence is rather complete and was deposited at the peri-Gondwanan platform (as for the CIZ), although differences in the faunal content and in the Paleozoic facies, generally more pelitic in the OMZ, point to a more distal position (Robardet, 2002; Robardet and Gutiérrez Marco, 1990). Ediacaran-Cambrian and Cambro-Ordovician magmatism reflects two rifting events, the latter including alkaline magmatism related to the opening of the Rheic Ocean (García Casquero et al., 1985; Ochsner, 1993; Sánchez-García et al., 2008, 2010). The first deformation event, of Devonian age, formed overturned and recumbent folds and thrust faults with southwestern vergence (Expósito et al., 2002, 2003). Synorogenic, early-Carboniferous basins developed in an extensional context and are related to calc-alkaline volcanism and magmatism (Casquet et al., 2001). These deposits unconformably overlay early folds and thrusts. Later, deformation continued with middle- and upper-Carboniferous sinistral transpression and associated upright northwest-southeast folds.

A salient seismic reflector, the IBERSEIS reflective body (IRB; Carbonell et al., 2004; Simancas et al., 2003), located along a mid-crustal detachment, seems to be a mantlederived intrusion emplaced during early-Carboniferous extension (350-340 Ma). At this time, the hinterland to the northwest was undergoing the first stages of compression $\left(C_{1}-C_{2}\right)$.

\subsection{The South-Portuguese Zone (SPZ)}

The boundary between the OMZ and the SPZ has been long understood as a suture on the basis of geometric assumptions (e.g., Carvalho, 1972). Later evidence has reinforced this point of view, suggesting that it represents the remnants of the Rheic Ocean, although Carboniferous transtension and transpression have largely obliterated it (Pérez-Cáceres et al., 2015, and references therein).

The SPZ is a Variscan foredeep basin strongly deformed by thin-skinned thrust tectonics, and it is usually correlated with the Rhenohercynian Zone of Kossmat (1927), in the Bohemian Massif. It features wide outcrops of low- or verylow-grade Devonian phyllites, quartzites, and sandstones overlain by a lower-Carboniferous (early-Mississippian) volcano-sedimentary sequence topped by middle- and upperCarboniferous flysch (Oliveira, 1990). From a tectonic point of view, it is characterized by Carboniferous south-vergent thrusts and folds, the latter featuring axial traces oblique to the northern boundary of the zone, evidencing transpression (Simancas et al., 2003, and references therein). Deformation propagated towards the south during the lower and upper Carboniferous (Oliveira, 1990).

Although the start of the Variscan collision seems to have been frontal or maybe right-lateral in most of Europe (Shelley and Bossière, 2000), surface geology and interpretation of seismic data evidence the existence of relevant left-lateral transpression and oblique-slip syn-metamorphic shear zones in the OMZ, SPZ, and their boundaries (Pérez-Cáceres et al., 2016; Simancas et al., 2003, and references therein). In the OMZ, folds and thrusts witnessing Devonian and earlyCarboniferous compression are oblique to the OMZ-SPZ boundary, indicating a transpressional setting. There, Devonian and Carboniferous left-lateral deformation accounts for $\sim 400 \mathrm{~km}$, which is higher than perpendicular shortening. Likewise, inside the SPZ, left-lateral displacement is estimated to reach $90 \mathrm{~km}$, whereas the orthogonal one amounts to $\sim 60 \mathrm{~km}$ (Pérez-Cáceres et al., 2016).

\section{Geophysical setting: existing datasets, their reprocessing, and a brief description}

\subsection{Seismic datasets sampling the Iberian Massif}

Since the early 1990s, the Iberian Massif has been sampled by different controlled source seismic experiments (DeFelipe et al., 2021): the ESCIN (1991-1992), IBERSEIS (2000 and 2003), and ALCUDIA (2007-2012) experiments acquired normal incidence (NI) and coincident wide-angle (WA) data. The latest project, carried out with the target of understanding the structure and effect of the Alpine reactivation across the central part of the Iberian Massif, is the CIMDEF experiment (2017-2019). It recorded densely spaced controlled source WA reflection and natural source (earthquakes and noise) seismic data. However, the acquisition of coincident NI data along this transect has not currently been planned, regardless of its potential quality and relevance, due to the relatively high costs of this kind of experiment.

From north to south and from east to west, the ESCIN project sampled the northern part of the Iberian Massif (Fig. 1). Profile ESCIN-1 (1991) is an onshore east-west line crossing the $\mathrm{CZ}$ from its eastern, most external part to its boundary with the WALZ to the west; Profile ESCIN2 (1991) is an onshore north-south profile crossing the most external and eastern part of the $\mathrm{CZ}$ and reaching the northern end of the Duero Basin (DB) to the south, which represents the Cantabrian Mountains foreland basin. The ESCIN3 (1992) profiles sampled the WALZ and the CIZ along the northern Iberian shelf. Although it consists of three parts (ESCIN-3.1, 3.2, and 3.3), only the easternmost ones (3.2 and 3.3.) are relevant for this study and are, thus, included here. ESCIN-3.3 crossed the entire WALZ to its western boundary with the CIZ, which was surveyed by the ESCIN-3.2 in this area. Geographically, the latter also sampled the allochthonous GTMZ. However, as this is an offshore profile, it shows no evidence of the presence of the GTMZ, and most of the imaged crust corresponds to that of its relative autochthon, the CIZ.

A significant geographical and methodological gap exists between the ESCIN profiles to the north and the location of the CIMDEF experiment (Fig. 1). The latter crosses central Iberia from the northern part of the CIZ, samples the DB 
down to the ICS, and the goes on south across the Tajo Basin (TB) until it reaches the CIZ metasediments again.

In the southern part of the Iberian Massif, the onshore ALCUDIA seismic line (NI and WA), striking northeastsouthwest, was acquired across the CIZ, going from the south of the ICS to the boundary with the OMZ. Finally, the northeast-southwest IBERSEIS dataset (NI and WA) is also an onshore profile that structurally overlaps the southwestern end of the ALCUDIA line, although with some $50 \mathrm{~km}$ of offset to the west. This seismic line samples the southern part of the CIZ, the OMZ, and the SPZ.

Altogether these seismic profiles account for a $\sim 1500 \mathrm{~km}$ long seismic transect geared to understand the crustal and, in places, lithospheric structure of the Iberian Massif and to constrain its evolution.

\subsection{Processing of datasets}

The data used in this work have been acquired at different times, have different characteristics (onshore and offshore), and, accordingly, exhibit very heterogeneous quality. Table 1 shows their acquisition parameters. The most outstanding differences are (i) the quality and characteristics of the offshore (ESCIN-3) vs. the onshore data; (ii) the difference between the low fold (30) ESCIN data, acquired with explosive sources and airguns, and the high fold $(>60)$ IBERSEIS and ALCUDIA datasets, which used Vibroseis trucks as source of energy; and (iii) the fact that the CIMDEF dataset lacks NI data and only provides lower-resolution noise and earthquake data, as WA profiles are, as yet, unpublished. Thus, reprocessing all NI data was mandatory, at least at the stack and post-stack level. Figure 2 shows the processing flow followed to homogenize the display of datasets while preserving the true amplitude (Martínez García, 2019). The software package used for reprocessing was GLOBEClaritas (https: //www.globeclaritas.com/, last access: 3 July 2019), and the most important steps were related to frequency filtering, amplitude weighting and equalization, Kirchhoff time migration, and coherency filtering (Fig. 2). In addition, up to 20 multi-trace attribute analyses were tested with the goal of enhancing structural and lithological impedance contrasts that allowed for the improvement of the interpretation (Chopra and Alexeev, 2005; Taner and Sheriff, 1977). Although this methodology has been mostly used in sedimentary reservoirs, we have seen that the application of these techniques can enhance the continuity of reflections and help to identify different types of crust, thereby easing the interpretation. Some of the boundaries resulting from this attribute analysis (e.g., variance and chaos attribute filters, with the former estimating the local variance in the signal and the latter measuring the lack of organization in the reflectivity) are included in the interpretations.

\subsection{Description of the seismic sections}

The NI datasets included in this paper have already been presented; thus, in every subsection, the reader will be referred to previous publications that include detailed descriptions of pre-stack processing and interpretations. Here, we will just focus on those features that are essential to our interpretation.

Geological cross sections coincident with reprocessed time-migrated sections and their interpretations are presented in Fig. 3 (ESCIN-1), Fig. 4 (ESCIN-2), Fig. 5 (ESCIN-3.3), Fig. 6 (ESCIN-3.2), Fig. 7 (ALCUDIA), and Fig. 8 (IBERSEIS). Migration velocities (Fig. 2) are average crustal values as calculated from coincident or nearby WA models. Depth conversion using migration velocities is also carried out. The description of sections will be done from north to south and from east to west. The CIMDEF dataset will be only described in Sect. 4 (Figs. 9, 10) as it does not include NI data but is key to understanding the geometry of the mid-crustal discontinuity, its late-Variscan reworking, and its Alpine reactivation.

\subsubsection{Cantabrian Zone (ESCIN-1 section)}

The ESCIN-1 section is a $\sim 130 \mathrm{~km}$ long, east-west profile crossing the $\mathrm{CZ}$ from its most external part to the Narcea Antiform to the west, at the boundary with the hinterland (WALZ; Figs. 1, 3). The section, migrated at $v=5600 \mathrm{~m} / \mathrm{s}$ (Fig. 2) and its interpretation is presented in Fig. 3.

This profile was first described and interpreted over an unmigrated image by Pérez-Estaún et al. (1994). Later works revisited the interpretation, adding travel-time modeling to help with understanding the unmigrated data (Gallastegui et al., 1997). The reader is referred to these papers for further details (in addition to those provided here).

In the upper crust, the western part shows west-dipping reflections that represent the Variscan imbrication, through a thrust ramp ( $t$ in Fig. 3), of the basement under the Paleozoic succession, indicating the proximity of the hinterland (WALZ). In fact, a Neoproterozoic, non-metamorphic sequence outcrops in this area, which is probably underlain by an older crystalline basement. Another prominent westdipping reflection roughly parallel to $t\left(t^{\prime}\right)$ crosscuts subhorizontal ones, defining a pattern that might be providing an out-of-plane image of the abovementioned thrust ramp, as this profile lies in the hinge of an arcuate structure, the IAA (Fig. 1b). To the east, the thin-skinned tectonics characteristic of this external zone can be interpreted from shallow subhorizontal to west-dipping reflections often coincident with outcropping thrusts (ot), as observed in Fig. 3a. The main one among these, running at around $5 \mathrm{~s}$ (TWT), is interpreted as the sole thrust of the thin-skinned orogenic wedge (st). To the west, it becomes involved in the crustal ramp (t in Fig. 3) observed at the Narcea Antiform, suggesting that it ends down rooting into the upper part of the lower crust (c in Fig. 3). 


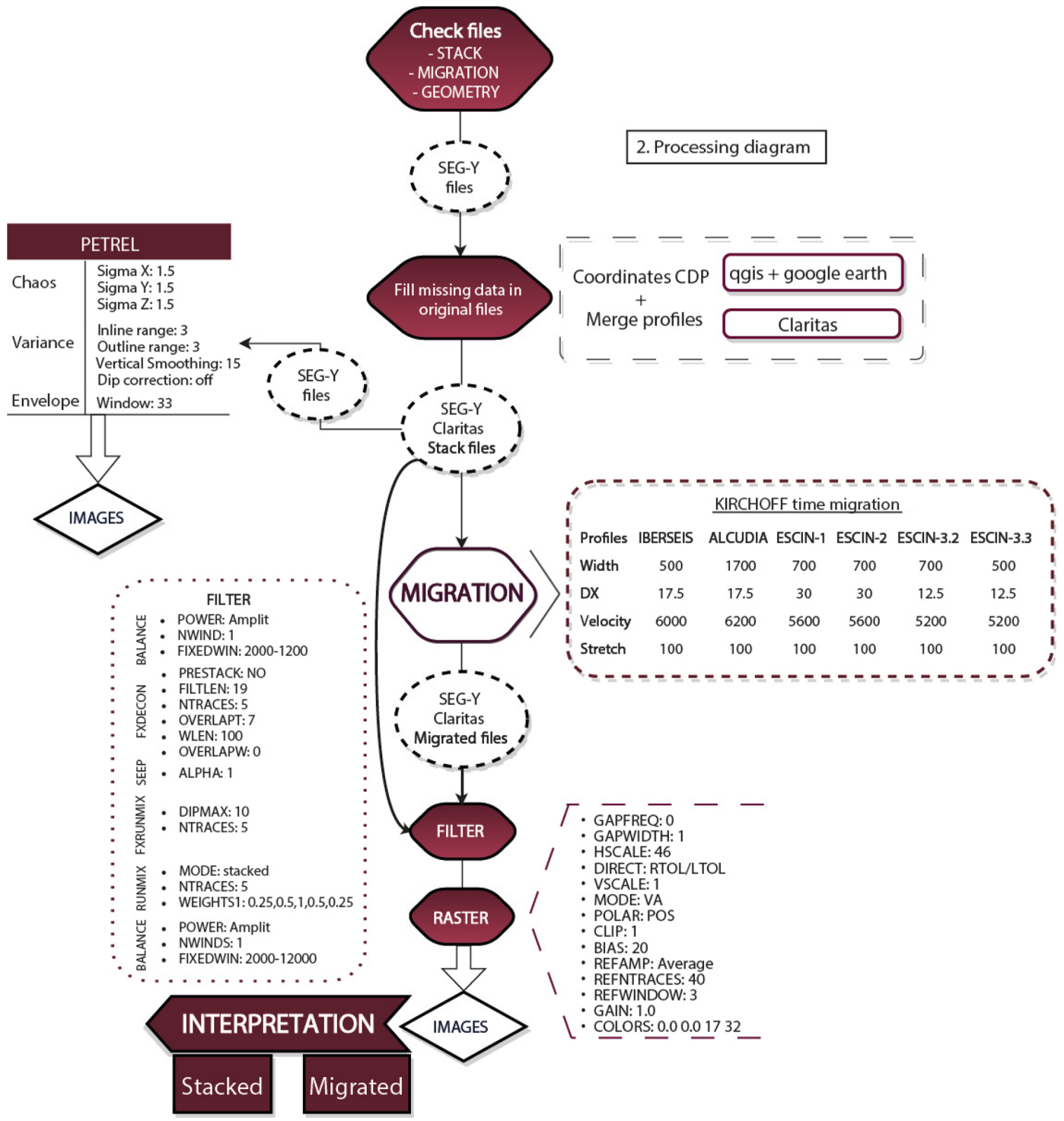

Figure 2. Processing flow carried over the SEG-Y original stack sections. This task was geared to improve and homogenize the resolution of the seismic images while creating new migrated sections. See Martínez García (2019) for further details.

A low-reflectivity wedge of undifferentiated basement $(b$ in Fig. 3) located between 4-5 and 8.5 s (TWT) exists underneath the easternmost reflections. This may image some prePaleozoic basement that is interpreted as upper crust, as the pattern of reflections changes below, suggesting that a significant boundary occurs underneath.

The lower crust shows little reflectivity but seems to be present in the interval between 8.5 and $14 \mathrm{~s}$ (TWT) in the east and between 8.5 and $12 \mathrm{~s}$ (TWT) in the west. It features subhorizontal (ir) and west-dipping internal reflectivity to the east, with the latter (ir') crosscutting the former reflections. These might represent the imprint of Alpine tectonics over a previously deformed/reflective lower crust. To the west, reflectivity seems to be subhorizontal or dipping to the east (ir). Some of the dipping and arcuated reflectivity observed at the edges of section ESCIN-1 (mig in Fig. 3 and thereafter) might be related to the migration effects over discontinuous features and caution should be taken when interpreting it.

The Moho along this section $(\mathrm{m})$ is located at nearly $14.5 \mathrm{~s}$ TWT $(\sim 45 \mathrm{~km})$ in the eastern part and is shallower $(12 \mathrm{~s}$ TWT, $\sim 36 \mathrm{~km}$ ) to the west. The crustal thickening observed to the east is probably related to an out-of-section image of the crustal Alpine root, better observed in profile ESCIN-2, which is described next.

\subsubsection{Cantabrian Zone and Duero Basin (ESCIN-2 section)}

The ESCIN-2 seismic line is a $65 \mathrm{~km}$ long, north-south section that samples the transition between the $\mathrm{CZ}$ and the $\mathrm{DB}$ 

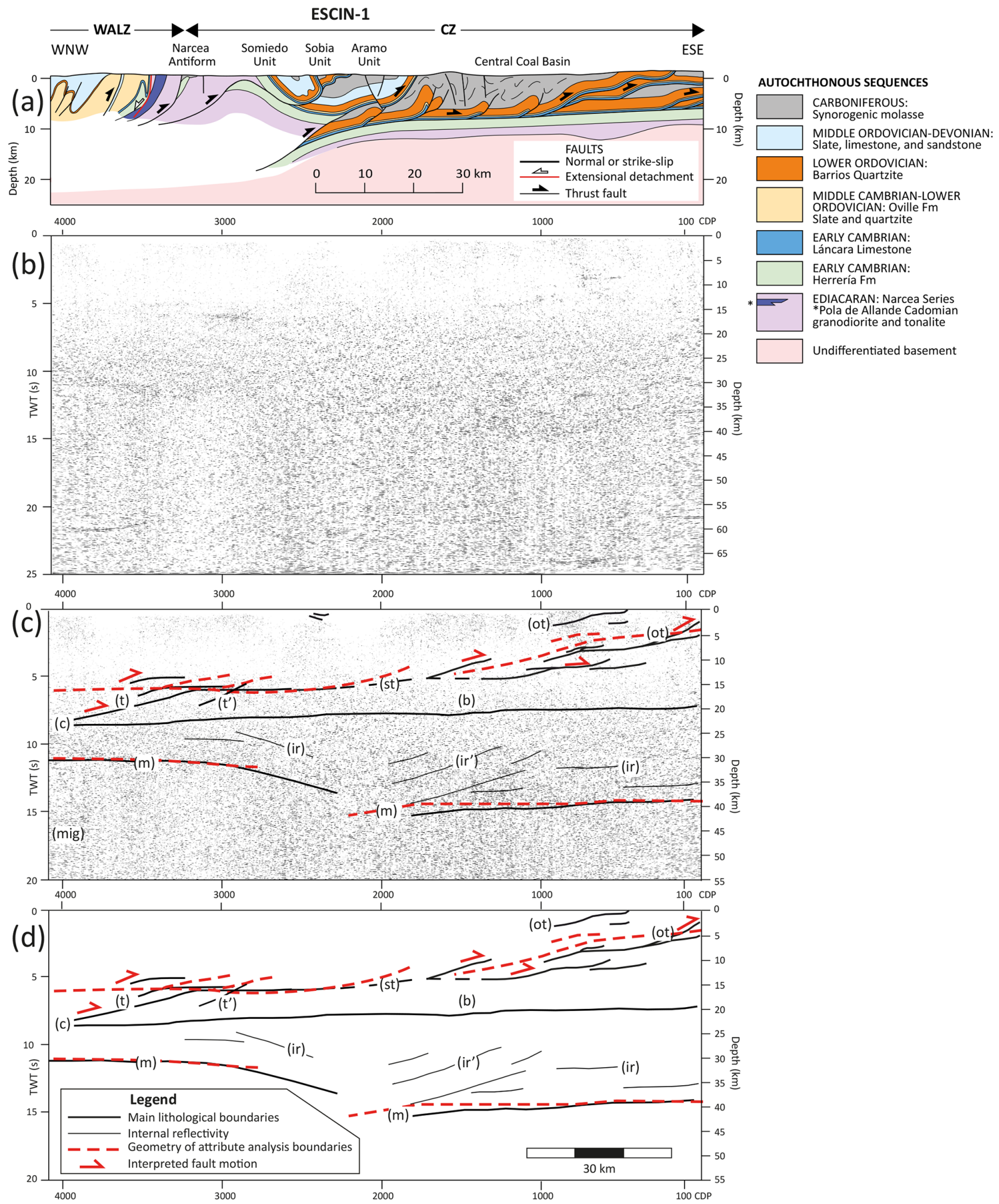

Figure 3. Cross section (a) and depth-converted time-migrated section $(v=5600 \mathrm{~m} / \mathrm{s})$ along the NI seismic profile ESCIN-1 (Fig. 1), without (b) and with (c) interpretation. A sketch of the most important features is presented in panel (d). The abbreviations used in the figure are as follows: CDP is the common depth point, TWT is the two-way travel time, WALZ is the West Asturian-Leonese Zone, and CZ is the Cantabrian Zone. The position of the Narcea Antiform is indicated. Red dashed lines represent the boundaries provided by chaos and variance attribute analyses. The nomenclature for reflections is as follows: (ot) denotes outcropping thrusts, (t) denotes thrusts affecting the basement, (b) is undifferentiated basement, (st) is sole thrust, (c) is top of the lower crust, (ir) is the lower crust internal reflectivity, (m) is the Moho, and (mig) denotes curved features resulting from the migration of discontinuous reflections. Depth conversion is based on migration velocities. 

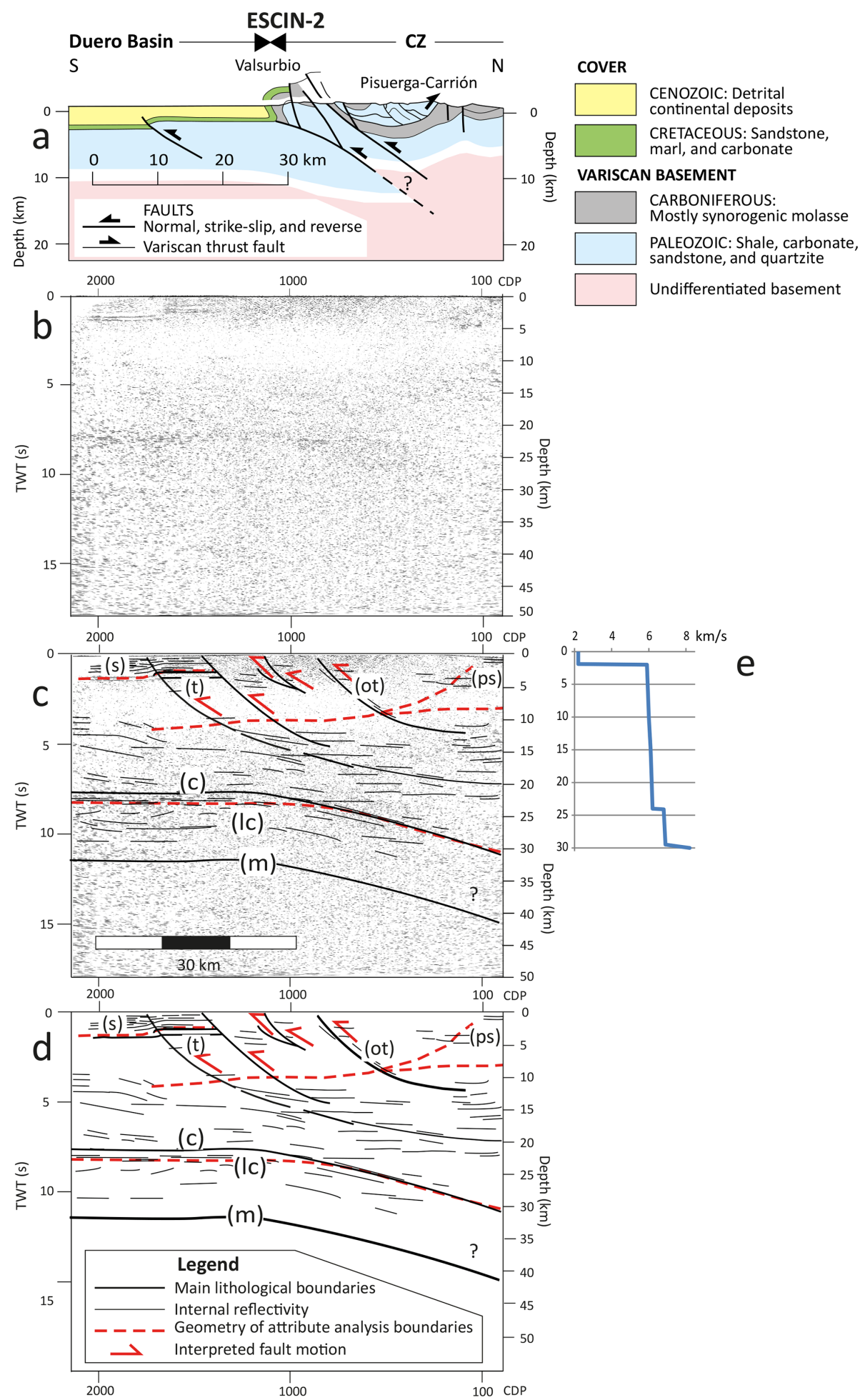

Figure 4. Cross section (a) modified from Gallastegui et al. (2016) and the depth-converted time-migrated section ( $\mathrm{v}=5600 \mathrm{~m} / \mathrm{s})$ of the NI seismic profile ESCIN-2 (Fig. 1), without (b) and with (c) interpretation. A sketch of the most important features is presented in panel (d). A 1D velocity profile as modeled from wide-angle data (Pulgar et al., 1996) appears in panel (e). The abbreviations used in the figure are as follows: CDP is the common depth point, TWT is the two-way travel time, and CZ is the Cantabrian Zone. Some discontinuous reflections are traced on the basis of their geometry on the stack image (Pulgar et al., 1996). Red dashed lines represent the boundaries provided by chaos and variance attribute analyses. The nomenclature for reflections is as follows: (s) is sediments, (t) is thrusts, (ot) denotes outcropping thrusts, (ps) is Paleozoic sediments, (c) is top of the lower crust, (lc) is the lower crust, and (m) is the Moho. Depth conversion is based on migration velocities. 

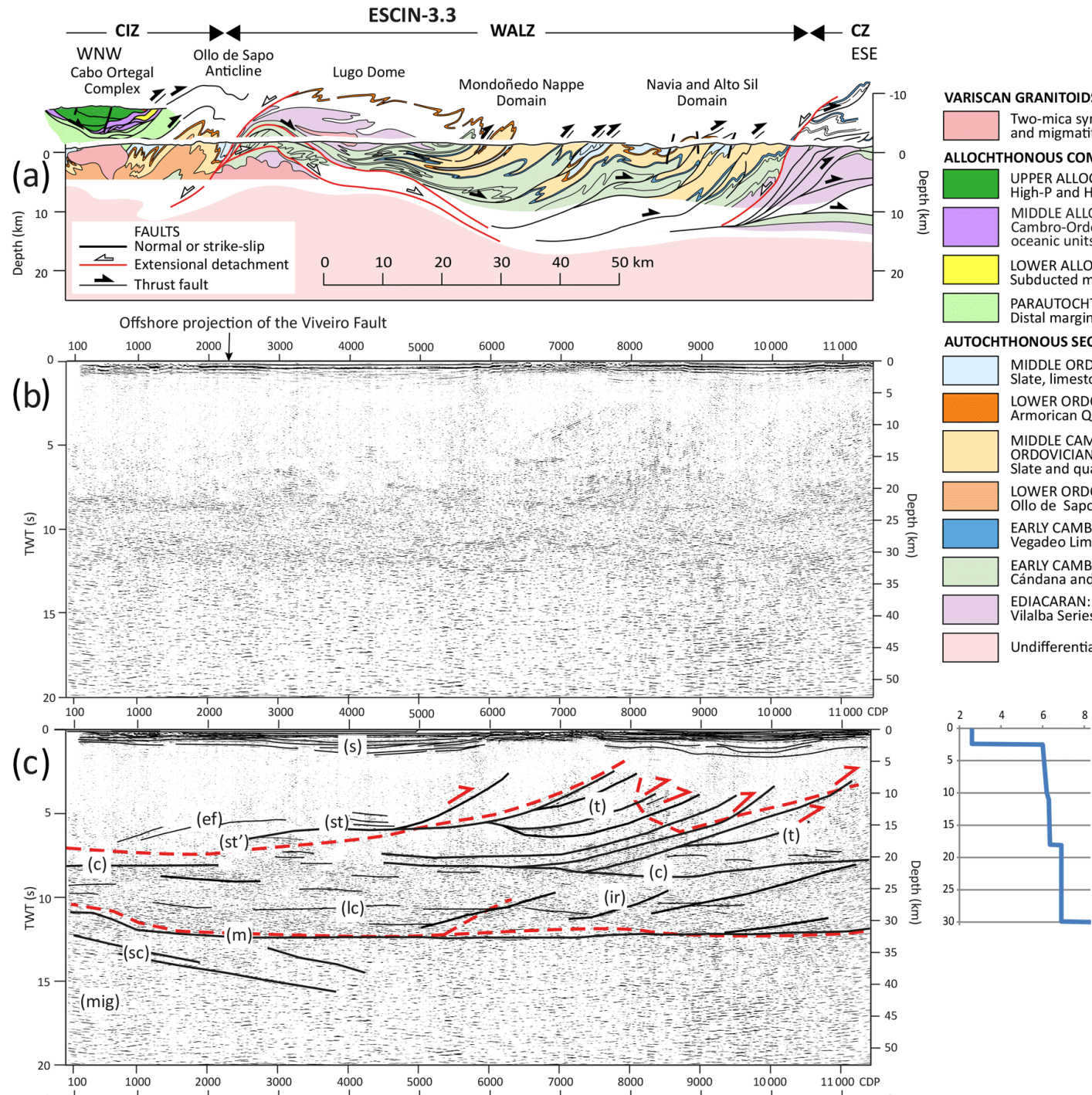

(e)

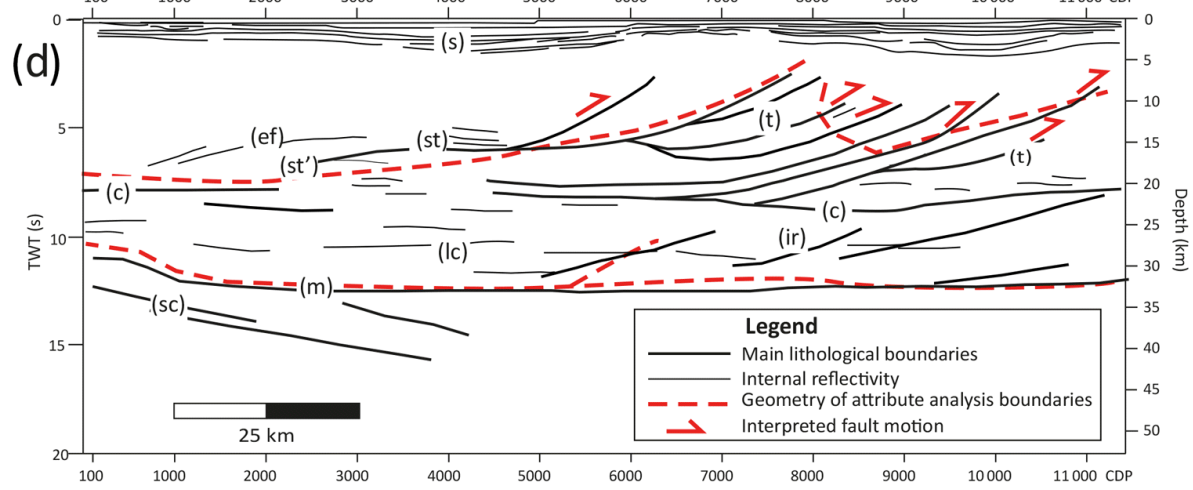

Figure 5. Cross section (a) and depth-converted time-migrated section ( $v=5200 \mathrm{~m} / \mathrm{s})$ of the NI seismic profile ESCIN-3.3 (Fig. 1$)$, without (b) and with (c) interpretation. A sketch of the most important features is presented in panel (d). A 1D velocity profile as modeled from wide-angle data (Ayarza et al., 1998) is presented in panel (e). The abbreviations used in the figure are as follows: CDP is the common depth point, TWT is the two-way travel time, CZ is the Cantabrian Zone, WALZ is the West Asturian-Leonese Zone, and CIZ is the Central Iberian Zone. The offshore projection of the Viveiro Fault is indicated. Red dashed lines represent the boundaries provided by chaos and variance attribute analyses. The nomenclature for reflections is as follows: (s) is sediments, (t) is thrusts, (st) denotes sole thrust, (ef) denotes extensional features, (c) is the top of the lower crust, (lc) is the lower crust, (ir) is the lower crust internal reflectivity, (m) is the Moho, (sc) denotes subcrustal reflections, and (mig) denotes curved features resulting from the migration of discontinuous reflections. Depth conversion is based on migration velocities. 

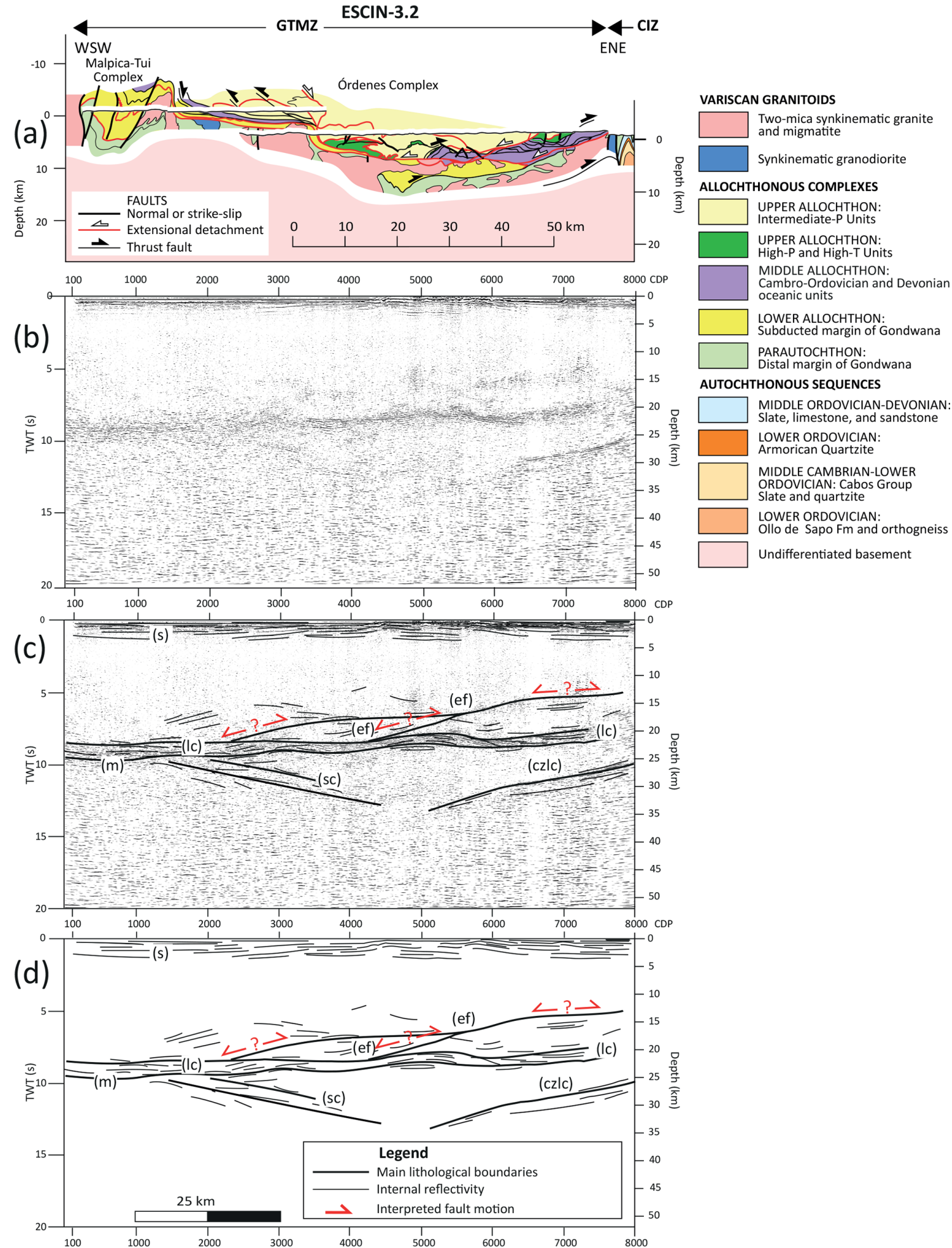

Figure 6. Cross section (a) and depth-converted time-migrated section $(v=5200 \mathrm{~m} / \mathrm{s})$ of the NI seismic profile ESCIN-3.2 (Fig. 1$)$, without (b) and with (c) interpretation. A sketch of the most important features is presented in panel (d). The abbreviations used in the figure are as follows: CDP is the common depth point, TWT is the two-way travel time, GTMZ is the Galicia-Trás-os-Montes Zone, CIZ is the Central Iberian Zone. The nomenclature for reflections is as follows: (s) is sediments, (ef) denotes extensional features, (lc) is the lower crust, (m) is the Moho, (sc) denotes subcrustal reflections, and (czlc) is the CZ underthrusted lower crust. Depth conversion is based on migration velocities. 

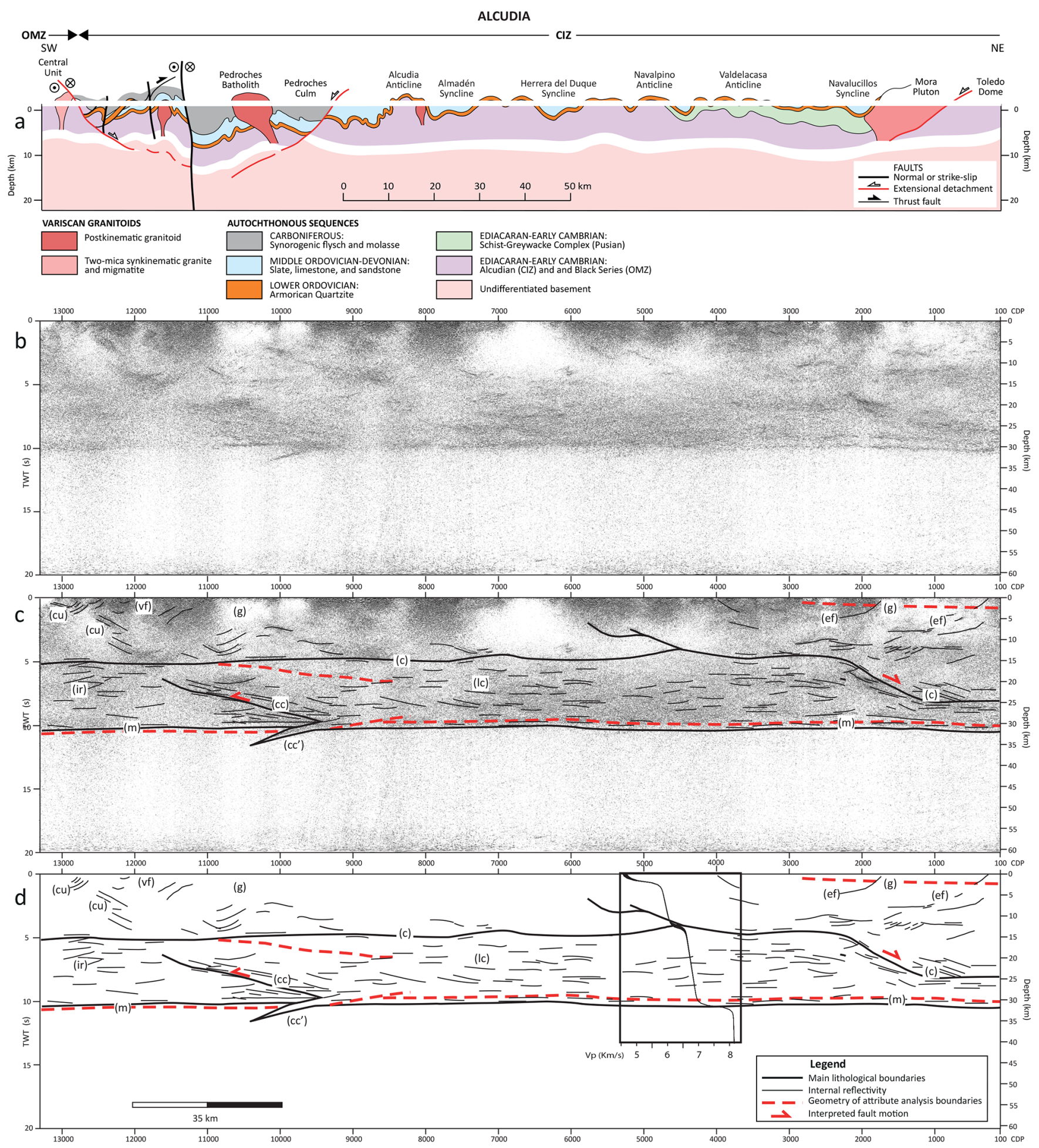

Figure 7. Cross section (a) modified from Martínez Poyatos et al. (2012) and the depth-converted time-migrated section ( $v=6200 \mathrm{~m} / \mathrm{s})$ of the NI seismic profile ALCUDIA (Fig. 1), without (b) and with (c) interpretation. A sketch of the most important features is presented in panel (d). A 1D velocity profile as modeled from wide-angle data (Palomeras et al., 2021) is overlapped in panel (d). The abbreviations used in the figure are as follows: CDP is the common depth point, TWT is the two-way travel time, CIZ is the Central Iberian Zone, and $\mathrm{OMZ}$ is the Ossa-Morena Zone. The nomenclature for reflections is as follows: (cu) is the central unit, (vf) denotes vertical folds, (g) denotes granites, (ef) denotes extensional features, (c) is the top of the lower crust, (lc) is the lower crust, (cc) and (cc') denote crocodile structure, and $(\mathrm{m})$ is the Moho. Red dashed lines represent the boundaries provided by chaos and variance attribute analyses. Depth conversion is based on migration velocities. 
Table 1. Acquisition parameters of the NI seismic profiles shown in Figs 3-8 and the former processing flows. These are grouped according to their similarities.

\begin{tabular}{|c|c|c|}
\hline Acquisition parameters & ESCIN-1 (onshore) & ESCIN-2 (onshore) \\
\hline Source & Dynamite-single-hole & Dynamite-single-hole \\
\hline Charge & $20 \mathrm{~kg}$ at $24 \mathrm{~m}$ depth & $20 \mathrm{~kg}$ at $24 \mathrm{~m}$ depth \\
\hline Trace interval & $60 \mathrm{~m}$ & $60 \mathrm{~m}$ \\
\hline No. of traces & 240 & 240 \\
\hline Spread configuration & Symmetrical split-spread & Symmetrical split-spread \\
\hline Fold & 30 & 30 \\
\hline Geophones per group & 18 & 18 \\
\hline Spread length & $14.5 \mathrm{~km}$ & $14.5 \mathrm{~km}$ \\
\hline Sample rate & $4 \mathrm{~ms}$ & $4 \mathrm{~ms}$ \\
\hline \multirow[t]{2}{*}{ Kirchoff time migration } & $5600 \mathrm{~m} / \mathrm{s}$ & $5600 \mathrm{~m} / \mathrm{s}$ \\
\hline & \multicolumn{2}{|c|}{ ESCIN-3.2 and ESCIN-3.3 (offshore) } \\
\hline Source & Airgun (5490 cu.in) & \\
\hline Shot spacing & $75 \mathrm{~m}$ & \\
\hline Receiver interval & $12.5 \mathrm{~m}$ & \\
\hline Spread length & $4500 \mathrm{~m}$ & \\
\hline Fold & 30 & \\
\hline Internal offset & $240 \mathrm{~m}$ & \\
\hline Sample rate & $4 \mathrm{~ms}$ & \\
\hline Record length & $20 \mathrm{~s}$ & \\
\hline \multirow[t]{2}{*}{ Kirchoff time migration } & $5200 \mathrm{~m} / \mathrm{s}$ & \\
\hline & IBERSEIS (onshore) & ALCUDIA (onshore) \\
\hline Source & $4,22 \mathrm{~T}$ vibrators & $4(+1), 22 \mathrm{~T}$ vibrators \\
\hline Recording instrument & Sercel $388,10 \mathrm{~Hz}$ & Sercel $388,10 \mathrm{~Hz}$ \\
\hline No. active channels & 240 minimum & 240 minimum \\
\hline Station spacing & $35 \mathrm{~m}$ & $35 \mathrm{~m}$ \\
\hline Station configuration & 12 geophones & 12 geophones \\
\hline Source spacing & $70 \mathrm{~m}$ & $70 \mathrm{~m}$ \\
\hline Sweep frequencies & Nonlinear $8-80 \mathrm{~Hz}$ & Nonlinear $8-80 \mathrm{~Hz}$ \\
\hline Sweep length & $20 s$ & $20 s$ \\
\hline Listening time & $40 \mathrm{~s}$ & $40 s$ \\
\hline Sample rate & $2 \mathrm{~ms}$ & $4 \mathrm{~ms}$ \\
\hline Spread type & Asymmetric split-spread & Asymmetric split-spread \\
\hline Nominal fold & 60 (minimum) & 60 (minimum) \\
\hline Kirchoff time migration & $6000 \mathrm{~m} / \mathrm{s}$ & $6200 \mathrm{~m} / \mathrm{s}$ \\
\hline
\end{tabular}

(Fig. 1). Even though this profile was geared to study the Alpine structures, it shows how the Variscan features have been reactivated during the Cenozoic compression between the Iberian Peninsula and the European Plate. The section was first presented by Pulgar et al. (1996). Some authors have subsequently used this image to constraint the Alpine structure in the North Iberian Margin (e.g., Fernández-Viejo et al., 2000; Gallastegui et al., 2016). However, only Teixell et al. (2018) used a migrated version $(4000 \mathrm{~m} / \mathrm{s})$ of this section. Here, we present the results of a Kirchhoff time migration at $v=5600 \mathrm{~m} / \mathrm{s}$ (Fig. 4).

In places, this seismic line shows a conspicuous reflectivity that allows a straightforward interpretation. Toward the southern end, the upper crust is characterized by highamplitude horizontal reflectivity representing the DB sedi- mentary sequence (Fig. 4a). It occupies the interval from 0 to $3.5 \mathrm{~s}$ TWT ( $s$ in Fig. 4b, c, and d) and appears to be offset by north-dipping reflections $(\mathrm{t})$. The latter have been interpreted as south-vergent Alpine thrusts affecting the $\mathrm{CZ}$ basement and partly the DB sediments. The rest of the crust is less reflective, although north-dipping reflectivity (ot), also interpreted as Alpine thrusts on the basis of the clearer stack image (Pulgar et al., 1996), crosscuts shallow subhorizontal weak reflections that represent the Paleozoic sedimentary sequence of the $\mathrm{CZ}$ (ps).

The lower crust presents higher-amplitude reflectivity. In general, a thick band of horizontal reflections located between 7.5 and $12 \mathrm{~s}$ (TWT) in the southern part of the profile, bends and dips to the north in the northern part of the line (lc) in response to Alpine compression. Although 


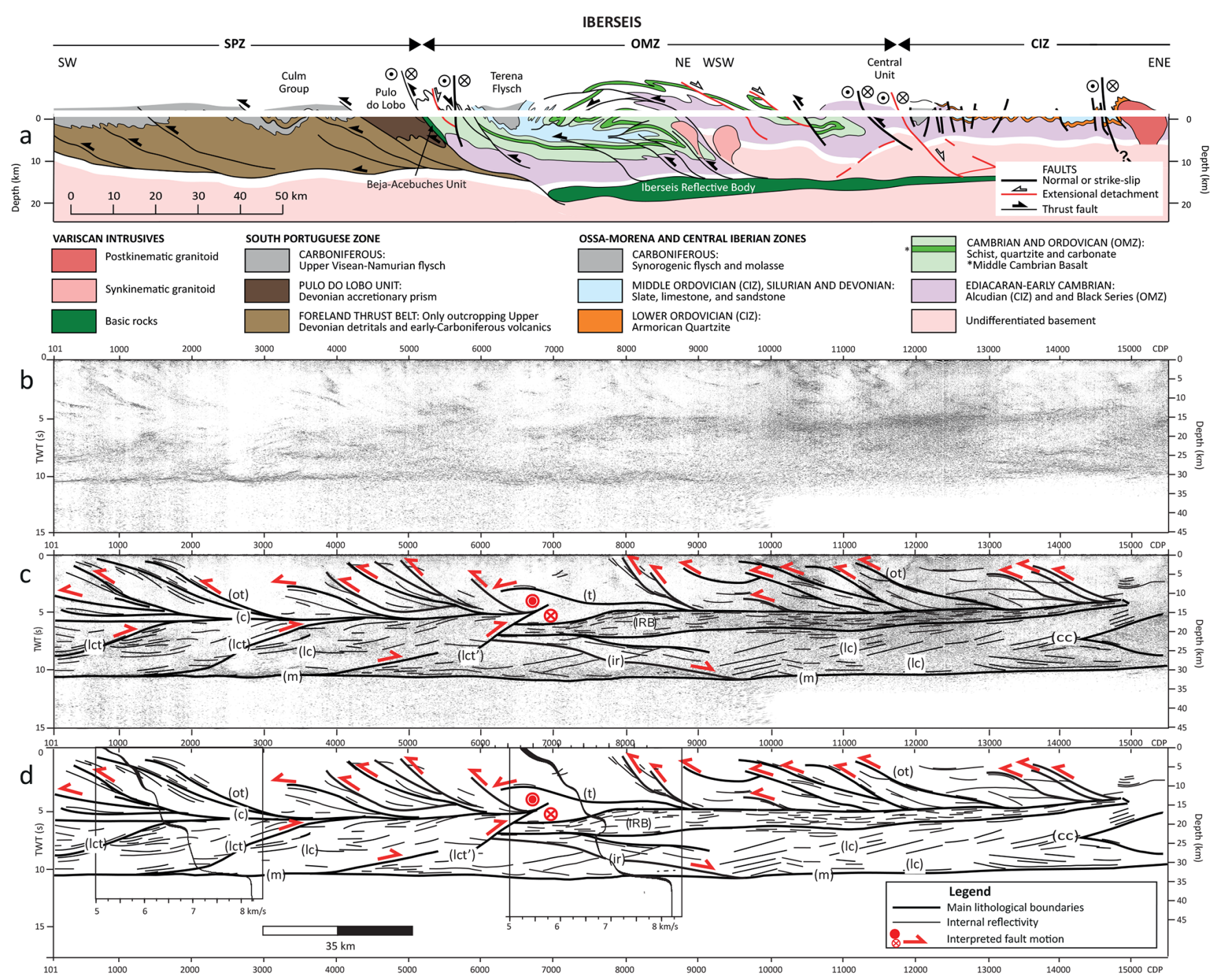

Figure 8. Cross section (a) modified from Simancas et al. (2003) and depth-converted time-migrated section $(v=6000 \mathrm{~m} / \mathrm{s})$ of the NI seismic profile IBERSEIS (Fig. 1), without (b) and with (c) interpretation. A sketch of the most important features is presented in panel (d). Two 1D velocity profiles as modeled from wide-angle data (Palomeras et al., 2009) are overlapped in panel (d).The abbreviations used in the figure are as follows: CDP is the common depth point, TWT is the two-way travel time, CIZ is the Central Iberian Zone, OMZ is the Ossa-Morena Zone, and SPZ is the South Portuguese Zone. The nomenclature for reflections is as follows: (t) denotes thrusts, (ot) denotes outcropping thrusts, (IRB) is the IBERSEIS reflective body, (c) is the top of the lower crust, (lc) is the lower crust, (ir) is the lower crust internal reflectivity, (lct) denotes lower-crust thrusts, and $(\mathrm{m})$ is the Moho. Depth conversion is based on migration velocities.

the stacked section shows that this north-dipping reflectivity reaches $14.5 \mathrm{~s}$ TWT (Pulgar et al., 1996), the migrated sections (Teixell et al., 2018, and Fig. 4) indicate that these reflections move southward and upward to less than $14 \mathrm{~s}$ (TWT) while losing amplitude and coherence. In fact, the geometry of the bottom of the lowermost crust, Moho (m), is deduced on the basis of the geometry of its uppermost part (c), the lower crust internal reflectivity, the stack image (Pulgar et al., 1996), and the amplitude contrasts observed in the attribute analysis (Fig. 4). Furthermore, its depth is solely established on the basis of the position of the strongest subhorizontal reflections to the south.
Even though this profile shows the imprint of recent Alpine shortening, no reflections are observed to crosscut the entire crust. In contrast, reflectivity suggests that deformation is decoupled between the upper and lower crust. However, this section is not long and/or reflective enough to image where the Alpine thrusts (ot) root. Possibly, they merge into the roof of the underthrusted $\mathrm{CZ}$ lower crust.

A 1D $V p$ ( $P$-wave velocity) profile (Fig. 4e) extracted from the coincident WA model (Pulgar et al., 1996) shows a conspicuous velocity increase in the lower crust, at a depth roughly coincident with (c). Depth misfits are due to the ef- 


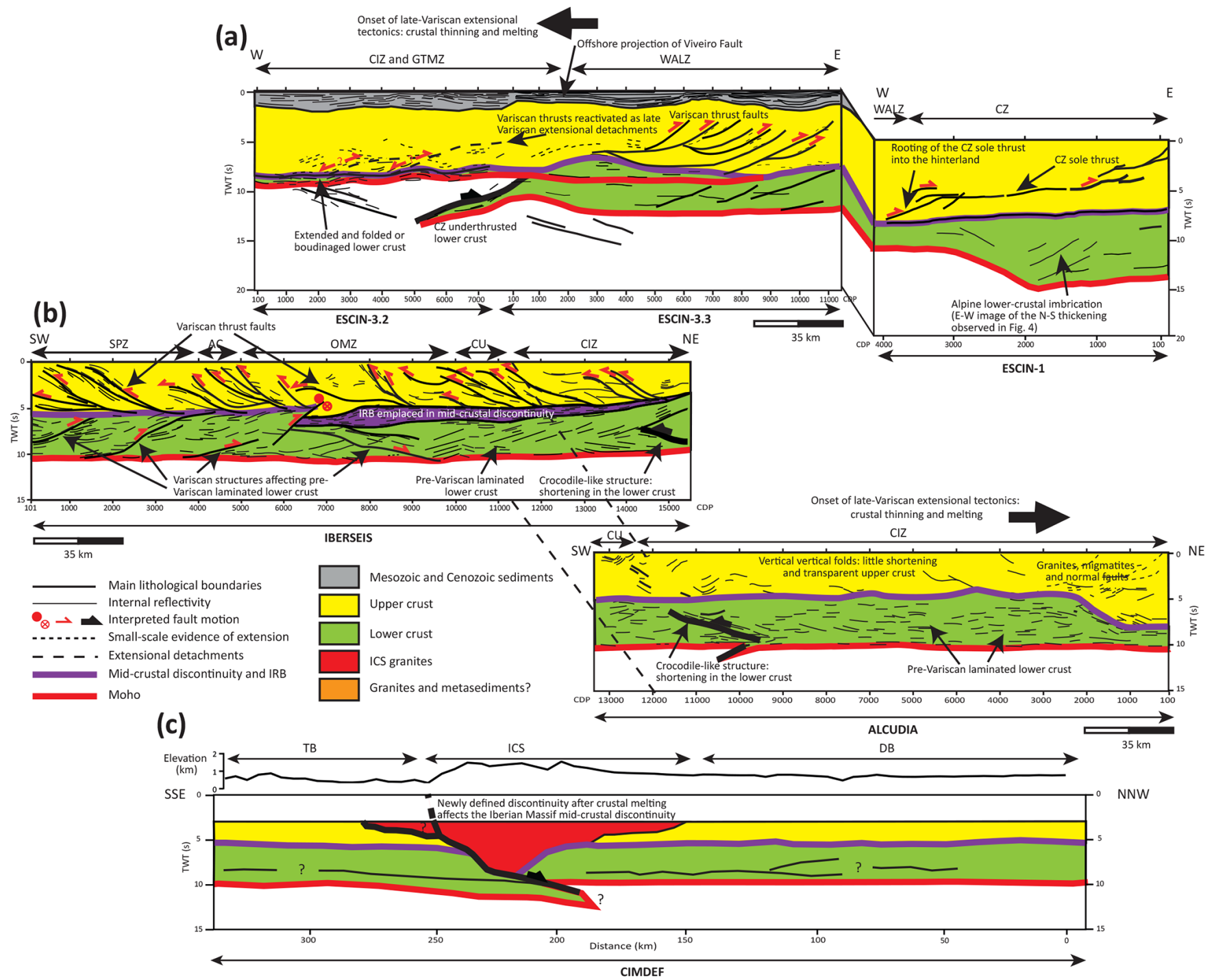

Figure 9. Joint geological interpretation of all of the seismic sections (normal incidence and seismic noise) whose location is shown in Fig. 1: (a) ESCIN-1, ESCIN3-3, and ESCIN-3.2; (b) ALCUDIA and IBERSEIS; and (c) CIMDEF (Andrés et al., 2020). Special attention should be paid to the depth and geometry of the Moho and mid-crustal discontinuity. Alpine structures (i.e., crustal thickening) appear in ESCIN-1 and in CIMDEF. The rest are Variscan features.

fect of the low $V p$ of the DB sediments not being taken into account in the depth conversion.

\subsubsection{West Asturian-Leonese Zone (ESCIN-3.3 section)}

The ESCIN-3.3 profile is part of a $\sim 375 \mathrm{~km}$ long crooked offshore seismic line consisting of ESCIN-3.1, 3.2 and 3.3. The latter is $137 \mathrm{~km}$ long and is parallel and close to coast across the WALZ (Fig. 1). The ESCIN-3.3 profile was first presented by Martínez Catalán et al. (1995) and Ayarza et al. (1998, 2004). Later on, its image was used to constrain the structure of the western North Iberian Margin and that of the transition between the WALZ and the CIZ (Martínez Catalán et al., 2012, 2014). The cross section in Fig. 5a represents the onshore transect of this profile.

Reflectivity in the upper crust is characterized by the image of Mesozoic sedimentary basins ( $s$ in Fig. 5) related to the extension that led to the opening of the Bay of Biscay. Underneath, west-dipping reflections $(\mathrm{t})$ are interpreted as the imprint of the first stages of Variscan compressional deformation in the WALZ $\left(C_{1}\right.$ and $\left.C_{2}\right)$, developing east-vergent thrust faults (Fig. 5a). These affect the pre-Paleozoic basement and root in the upper part (c) of a thick reflective band interpreted as the lower crust (lc) or in a sole thrust (st) that also reaches the lower crust.

The lower crust (lc) is represented by a thick band of subhorizontal reflectivity (8-12 s TWT) that thickens (6-12 s 

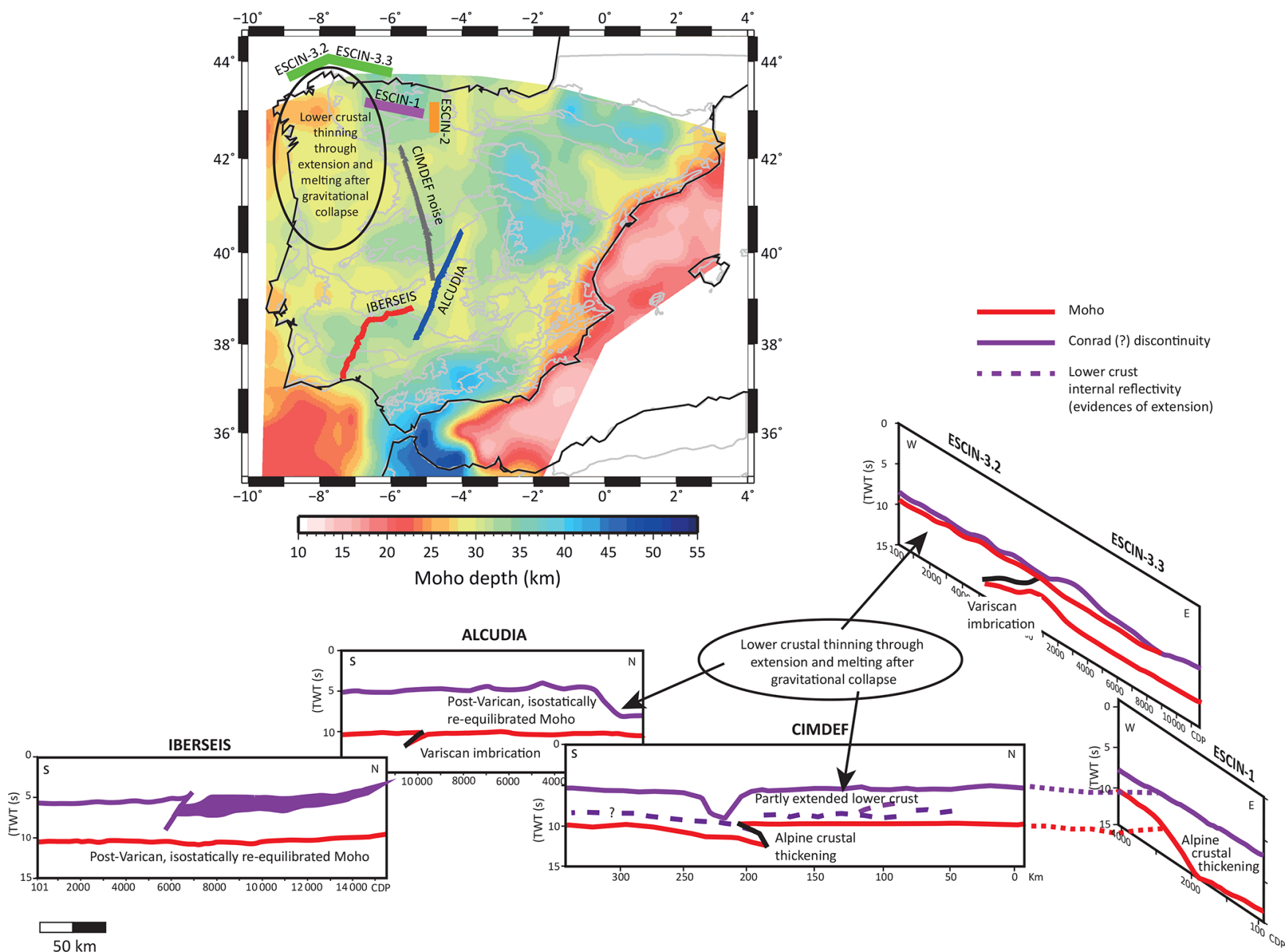

Figure 10. Map of the Moho depth as derived from tomography of shear waves (seismic noise and earthquakes; Palomeras et al., 2017) with the projection of the seismic profiles already shown in Fig. 1 and described in the text. A sketch of the geometry of the main discontinuities (Moho and Conrad) is also shown.

TWT) in the westernmost part of the WALZ (CDP 3000) underneath the Lugo Dome, an extensional structure bounded to the east by the Viveiro normal fault (Fig. 5). It then thins towards the end of the line, when entering the CIZ, coinciding with an area of east-dipping subcrustal reflections (sc); the sum of these reflections defines a less clear Moho (m) in this area. The ESCIN-3.3 lower crust seems to feature an internal layer with mantle P-wave velocities when modeled from coincident WA data. Accordingly it was interpreted as consisting of the WALZ lower crust underthrusted by the CZ lower crust (Ayarza et al., 1998). This model would compensate for the high shortening observed in the upper crust of the CZ, a thin-skinned belt whose sole thrust roots at the contact with the WALZ. The internal reflectivity of the lower crust shows west-dipping reflectors (ir), similar to the ones observed in the upper crust and probably imaging Variscan deformation in the lower crust, either compressional or extensional. They crosscut subhorizontal reflectivity, thus post- dating it. A 1D P-wave velocity profile (Fig. 5e) derived from coincident WA data (Ayarza et al., 1998) again shows an important increase in relation to the top of the lower crust (c).

Even though migration $(v=5200 \mathrm{~m} / \mathrm{s}$, Fig. 2$)$ over discontinuous reflections blurs the seismic section at the edges (mig in Fig. 5), reflectivity never seems to crosscut the crust and/or the Moho, indicating that deformation is decoupled at upper and lower crustal level. Subcrustal east-dipping reflections (sc) are interpreted as the out-of-plane image of the Alpine southward subduction of the Bay of Biscay oceanic crust (Ayarza et al., 1998, 2004), which is outside the scope of this paper.

The boundary between the WALZ and the CIZ is the Viveiro Fault, one of the most striking surface expressions of late-Variscan extensional tectonics, featuring a decompression of $\sim 4 \mathrm{kbar}$ or $14 \mathrm{~km}$ (Reche et al., 1998). To its west, gravitational collapse of a thickened crust and associated crustal extension and melting have played a key role 
in the orogenic evolution of the CIZ. However, to the east, crustal re-equilibration after $C_{1}$ and $C_{2}$ thickening was less important and igneous activity decreases. Even though this fault itself is not identified in the seismic section (Fig. 4), the reflectivity generally varies to both sides of it, featuring a thinner ( $9 \mathrm{~s}$ TWT vs. $12 \mathrm{~s}$ TWT) and more transparent crust to the west (Fig. 6). In fact, the geometry of some reflections (ef) in the boundary between the WALZ and the CIZ, above the thickest lower crust, and the subtractive way the sole thrust (st) merges with the lower crust (st') seem to indicate the effect of extensional tectonics, sometimes reactivating compressional structures (st-st' ${ }^{\prime}$ ). Such a reactivation has been described on the basis of structural and metamorphic considerations of the main WALZ thrust sheet (Alcock et al., 2009). Conversely, further to the east, reflectivity probably represents the geometry of preserved compressional deformation.

\subsubsection{Northern Central Iberian Zone (ESCIN-3.2 section)}

The seismic line ESCIN-3.2 is a $97 \mathrm{~km}$ long profile, also parallel and close to the coast, that samples the relative autochthon to the GTMZ, i.e., the CIZ (Figs. 1, 6). It was first described by Álvarez-Marrón et al. (1996) and later by Ayarza et al. (2004). Here, it is presented migrated at $v=5200 \mathrm{~m} / \mathrm{s}$ (Fig. 2). The cross section in Fig. 6a corresponds to the equivalent onshore transect of this profile and depicts allochthonous sequences not imaged by the NI data.

In the upper part, this profile shows a band of high subhorizontal reflectivity that coincides with the location of Mesozoic basins, as in profile ESCIN-3.3 ( $s$ in Fig. 6). The rest of the upper crust is not very reflective, although a couple of west-dipping reflections (ef) rooting in a thin band of strong reflectivity are observed. These reflections, located in the east of the section from 4.5 to $8 \mathrm{~s}$ TWT, define a sort of duplex, extensional or compressional, but later extended, indicating boudinage and crustal thinning. To the west, the upper crust is very transparent and just a few weak reflections can be observed.

The narrow reflective band at $8-9 \mathrm{~s}$ TWT represents the lower crust (lc) and is the most striking feature of this profile. Its $1 \mathrm{~s}$ TWT thickness contrasts with that observed in the neighboring ESCIN-3.3 and ESCIN-1 sections, which show a much thicker lower crust (4-5 s TWT). Reflectivity in this band is subhorizontal, although somewhat undulated, while the band itself is slightly inclined to the west. In the east, the Moho (m) is located above 9s TWT, the shallowest identified so far in the Iberian Massif. Subcrustal east-dipping reflections (sc) are again associated with the 3D image of the southward subduction of the oceanic crust of the Bay of Biscay during the Alpine convergence (Ayarza et al., 2004), whereas west-dipping features might be related to the $\mathrm{CZ}$ lower crust (czlc) also underthrusted underneath the easternmost part of the CIZ.
This profile samples the northern CIZ, where Variscan crustal thickening during $C_{1}$ and $C_{2}$ was most important. Consequently, later gravitational collapse triggered extensional tectonics and crustal melting, allowing the intrusion of granites and the development of extensional detachments (with associated metamorphic offsets). The image of line ESCIN-3.2 shows a transparent upper crust to the west, suggesting that granites occupy most of it, which is supported by on-land geological mapping. Some thrust faults, such as those imaged by west-dipping reflections in profile ESCIN3.3 , probably root along this section and are represented by the west-dipping reflections at the base of the upper crust. However, these were later flattened and/or reactivated as extensional detachments by crustal thinning (ef). The narrowness of the highly reflective lower crust here suggests that crustal thinning was largely accommodated at this level, as the upper crust basically has the same thickness as in the ESCIN-3.3 line (up to 6-7 s TWT). In addition, crustal melting might have also affected the top of the lower crust. However, even though large parts of the crust were melted, reflectivity exists deep in the upper crust, suggesting that crustal melting was not pervasive and/or reflectivity is linked to synor late-tectonic features.

\subsubsection{Southern Central Iberian Zone (ALCUDIA section)}

The ALCUDIA seismic profile was first presented by Martínez Poyatos et al. (2012) and reprocessed and further interpreted by Ehsan et al. (2014). It is a more than $220 \mathrm{~km}$ long, northeast-southwest seismic profile sampling the CIZ to the south of the ICS down to the boundary with the OMZ (Fig. 1). Here, we presented this section migrated and depth converted using a $v=6200 \mathrm{~m} / \mathrm{s}$ (Figs. 2, 7).

This profile presents a fairly transparent upper crust when compared with other nearby sections (e.g., IBERSEIS; Fig. 8), although scarce reflectivity exists to the south and coincides with the boundary (suture) between the CIZ and the OMZ, namely the central unit (CU; cu in Fig. 7), and with the presence of vertical folds (vf). Some very transparent zones (g) appear to be related to the existence of granitic batholiths. To the north, the intrusion of these granites, associated with the existence of normal faults (ef), is one of the pieces of evidence of extensional tectonics affecting the southern part of the CIZ. The rest of the upper crust shows weak and discontinuous reflectivity that responds to the existence of vertical folding affecting lithologies with little impedance contrast. In fact, deformation in the upper crust of this part of the CIZ is weak, with the absence of low-dipping structures typical of tangential tectonics.

The lower crust shows a very different image to that of the upper crust. It is a thick band, of up to $6 \mathrm{~s}$ TWT (from 4 to $10 \mathrm{~s}$ ), of mostly subhorizontal high-amplitude reflectivity (lc) that appears to be cut across by north-dipping reflectors (cc) at some points. South-dipping internal reflectivity 
is also identified, although it is more scarce (ir). The lower crust thins at the northern end of the profile, near the ICS, where intrusion of granites and other evidence of crustal reequilibration suggest that extension played a key role. Accordingly, we suggest that the mechanisms that triggered this lower crustal thinning are related to melting and extension and not to compression, as previously proposed (Ehsan et al., 2014; Martínez Poyatos et al., 2012), and that the northdipping reflectivity observed in the top of the lower crust (c) in that area is an expression of extensional tectonics.

One of the most striking features of this profile is the crocodile-like structure affecting the lower crust at around CMP (common midpoint) 10000 ( $\mathrm{cc}$ and $\mathrm{cc}^{\prime}$ ). This structure, most likely related to Variscan shortening, accommodates an important part of the deformation at the lower crustal level and evidences that subhorizontal reflectivity of the lower crust is pre-Variscan, thereby raising the question about its precise age and origin. Despite the presence of this feature in the depth continuation of the suture between the CIZ and the OMZ (Fig. 7a), reflectivity does not crosscut the whole crust, suggesting the existence of a detachment in the top of the lower crust. This contrasts with the presence in the upper crust (CU) of retro-eclogites with peak metamorphic conditions of $19 \mathrm{kbar}$ and $\sim 550^{\circ} \mathrm{C}$ (López SánchezVizcaíno et al., 2003). Finally, the Moho boundary (m) is located at a fairly constant depth ( $\sim 10$ s TWT, i.e., $30-33 \mathrm{~km})$, although the lower crust seems to be preserved and a local crustal imbrication into the mantle is observed underneath the crocodile-like structure. A 1D $V p$ profile (inset in Fig. 7d) from a coincident WA-data model (Palomeras et al., 2021) shows a conspicuous increase in values along more than $15 \mathrm{~km}$ starting in the top of the lower crust (c), thereby supporting its important thickness.

\subsubsection{The Central Iberia, Ossa-Morena, and South Portuguese zones (IBERSEIS section)}

The IBERSEIS seismic line was first presented by Simancas et al. (2003). A number of later works added information and details to its interpretation (e.g., Carbonell et al., 2004; Schmelzbach et al., 2007, 2008; Simancas et al., 2006). This section crosses the southernmost CIZ, the whole OMZ, and most of the external SPZ (Fig. 1). It samples two major boundaries interpreted as suture zones: that between the CIZ and the OMZ (CU, Azor et al., 1994) and the one bounding the OMZ and the SPZ, which has been largely affected by younger Carboniferous events (Pérez-Cáceres et al., 2015). The IBERSEIS profile structurally overlaps the ALCUDIA profile along $\sim 30 \mathrm{~km}$, but it is displaced some $50 \mathrm{~km}$ to the west. A cross section along this transect and its interpretation after migration at $v=6000 \mathrm{~m} / \mathrm{s}$ (Fig. 2) are shown in Fig. 8 .

This section is $\sim 300 \mathrm{~km}$ long and features an outstanding reflectivity at upper and lower crustal levels. In the upper crust, a wealth of north-dipping reflections (t in Fig. 8) image a south-verging thrust and fold belt. In the SPZ, these are most reflective and probably related to normal faults derived from the extension that led to the opening of the Rheic Ocean and later reactivated as thrusts during the late-Carboniferous compression. Some authors link the highest reflective features to the middle-Carboniferous volcano-sedimentary complex (Schmelzbach et al., 2008), which might have used these fractures as a conduit, thereby enhancing reflectivity. In the OMZ, north-dipping reflections probably image Variscan thrust faults (ot) as some coincide with such mapped structures. Their lesser reflectivity might indicate the lack of involvement in the thrusts of lithologies that increase the impedance contrast.

Upper-crustal reflectivity in both the ZOM and SPZ does not cross to the lower crust, rooting at a mid-crustal level that is transparent in the SPZ and does not have any particular expression itself but does coincide with the top of the lower crust (c). However, in the OMZ, a reflective layer exists at this depth: it has been defined as the IBERSEIS reflective body (IRB, Simancas et al., 2003), a $140 \mathrm{~km}$ long, highvelocity conductive feature (Palomeras et al., 2009) that is supposed to represent an early-Carboniferous mantle-derived intrusion. Its origin has been related to mantle plume activity that thinned the lithosphere and extracted mantle-derived melts from the ascending asthenosphere (Carbonell et al., 2004). Its surface expression is "intraorogenic" transtensional features (Rubio Pascual et al., 2013; Simancas et al., 2006). Alternatively, Pin et al. (2008) have suggested, based on geochemical constraints, a tectonic scenario of slab breakoff for this feature. Internal reflectivity along the IRB is mostly subhorizontal, probably due to the effect of the intrusion along a subhorizontal detachment, and evidences little imprint from Variscan deformation. The body is slightly inclined to the south, which is at odds with the detachment being the sole thrust of the OMZ upper-crustal imbricates; perhaps it was the sole thrust of the OMZ upper-crustal imbricates, but its inclination changed during subsequent deformation, as later suggested.

The lower crust shows slightly different patterns in the CIZ and OMZ on one side and the SPZ on the other. In the southernmost part of the CIZ and northern OMZ, north- and south-dipping reflections define a wedge (cc) that might be the western continuation of the crocodile-like structure observed in the ALCUDIA seismic line in an equivalent structural position (cc in Fig. 7). In this section, the limited crustal imbrication into the mantle identified in the ALCUDIA line (cc' in Fig. 7) is not observed, perhaps because it only occurs further to the north or east. This structure may be the reason why the IRB is shallower at this point, indicating that the latter is older than the crocodile compressional feature. The rest of the lower crust shows south-dipping and subhorizontal (lc) reflectivity that does not exhibit clear crosscutting relationships, thereby hindering their interpretation. However, near the boundary with the SPZ, this reflectivity seems to be affected by north-dipping features (ir) overprinting them. In the SPZ, the lower crust shows a more homoge- 
neous image, with subhorizontal reflectivity (lc) that is often cut across by longer-scale south-dipping features (lct) that postdate them. The latter probably represent fractures that firstly accommodated the extension linked to the opening of the Rheic Ocean and were then reactivated as thrusts during the late-Carboniferous compression and collision of the SPZ basement with the OMZ. The most conspicuous of these reflections (lct') cuts the IRB in its southern part and seems to offset the lower crustal upper boundary between the SPZ and the OMZ. Two 1D $V p$ profiles derived from coincident WA data (Palomeras et al., 2009) and shown as insets in Fig. 8d indicate a velocity increase starting at the top of lower crust (c) and along the IRB.

Even though the lower crust in the OMZ and SPZ shows dipping features, none of them cross to the upper crust, thereby rooting at a mid-crustal level as does the uppercrustal reflectivity. This again implies the existence of a discontinuity (c) in the mid-crust.

Despite crossing two suture zones and imaging part of a crocodile-like structure, the IBERSEIS profile shows a fairly flat Moho (m) located at $\sim 10 \mathrm{~s}$ TWT, the same apparent depth as in the ALCUDIA line $(30-33 \mathrm{~km})$. Its signature is very clear underneath the SPZ and a bit blurry below the IRB.

\section{Discussion}

Simancas et al. (2013) have already undertaken an integrated interpretation of most of the seismic sections presented here, focusing on the following: (i) the accommodation of orogenic shortening at the crustal scale; (ii) the relationships between convergence, crustal thickening, and collisional granitic magmatism; and (iii) the development of the Iberian Variscan oroclines. In this paper, the same sections are presented, but they have been reprocessed at the stack level and time migrated using a Kirchhoff algorithm. In addition, two extra sections that image the alleged mid-crustal discontinuity after the Alpine reactivation are taken into account. The first one is the north-south ESCIN-2 NI dataset (Fig. 4), in the CZ, where this discontinuity has remained untouched during late-Variscan evolution but was reactivated during the Alpine Orogeny. The second one results from the CIMDEF experiment, carried out in the CIZ across the ICS, where the mid-crustal discontinuity has probably been affected by crustal melting during the late-Variscan extension and by later Alpine reactivation. The latter sections fill a key gap existing in Simancas et al. (2013).

Figures 3-8 represent an effort to show a homogeneous seismic image of the Iberian Massif crust that eased its integrated interpretation. Next, we discuss the main observed features and how they contribute to the understanding of the structure and evolution of the Iberian Massif, adding constraints to the origin of the elevation of the central Iberian Peninsula. Figure 9 presents a simplified sketch of the crustal layers observed in the Iberian Massif. Figure 10 shows a compendium of the position of the mid-crustal discontinuity and the Moho depth (in TWT) along the entire Iberian Massif as deduced from seismic NI data and a map of the Iberian Peninsula Moho depth (Palomeras et al., 2017) that includes the position of the seismic profiles for comparison. We will refer to these figures throughout most of Sect. 4.

A particular feature of the southwestern Iberian Massif is the relevance of left-lateral shear zones associated with its suture boundaries. They displaced central and northern Iberia to the northwest with respect to southern Iberia (Simancas et al., 2013). The seismic sections do not provide constraints about this movement, as it is perpendicular to their layout. Thus, interpretations in these areas must be taken with caution.

\subsection{The upper crust in the Iberian Massif: a depth image of outcropping geology}

Most of the seismic sections display a moderate to thick upper crust (4 to $8 \mathrm{~s}$ TWT; Fig. 9), with very variable reflectivity. Reflections coincide with outcropping Variscan structures; thus, a link has been established. As such, northdipping reflectivity in the SPZ and the OMZ is related to south-vergent folds and thrust faults mapped at the surface. West-dipping reflections in the $\mathrm{CZ}$ are related to mapped thin-skinned thrusts. The same type of reflectivity observed in the WALZ, albeit reaching deeper levels and rooting in the lower crust, has been associated with thick-skinned thrust tectonics, which affects the pre-Paleozoic basement in the hinterland. The contrast of the upper-crustal SPZ seismic image with that of the $\mathrm{CZ}$ it particularly interesting, with both representing external zones. Whereas thrusts are observed to root in a shallow sole detachment in the latter, reflections/thrusts root in the lower crust in the former. This feature will be discussed in the next section.

Only a few seismic profiles feature a transparent upper crust. Lack of reflectivity has been associated with low fold data (ESCIN-1 and ESCIN-2; Figs. 3, 4) and, most importantly, with the existence of a re-equilibrated upper crust featuring large amounts of partial melting, as shown by voluminous outcropping granitoids (ESCIN-3.2 and north of ALCUDIA; Figs. 6, 7). The existence of vertical folds affecting little reflective monotonous lithologies also results in a fairly transparent upper crust in most of the ALCUDIA section (Fig. 7).

None of the upper-crustal reflections observed in the presented Iberian Massif NI seismic sections cut across the whole crust, always rooting in a sole thrust (parts of ESCIN1 and ESCIN-3.3; Figs. 3, 5) or in the lower crust (the rest of them). 


\subsection{The lower crust in the Iberian Massif: accommodation of shortening, extension, and its nature}

The Iberian Massif dataset presented here shows a very coherent image of the lower crust. Its reflectivity is high and usually subhorizontal. However, crosscutting relationships with later features of opposite dips evidence a multiphase origin for this reflectivity.

The SPZ, OMZ, WALZ, CZ and the southern CIZ show that this part of the crust is also thick (4 to $6 \mathrm{~s}$ TWT). However, the ESCIN-3.2 and the northern part of the ALCUDIA sections (Figs. 1, 6, 7) indicate that the lower crust is much thinner ( 1 to $2 \mathrm{~s}$ TWT) and irregular in the northern CIZ (ESCIN-3.2; Figs. 6, 9). This thin lower crust has been observed in areas characterized by outcropping syn-collisional granitoids (zone II of Simancas et al., 2013). These witness crustal re-equilibration processes triggered by gravitational collapse, extension, and crustal melting during the late Carboniferous. The straightforward conclusion is to attribute this thin lower crust to late-Variscan orogenic extension, which features at the surface high metamorphic offsets (chlorite to sillimanite zone, Díez Balda et al., 1995) and melting, implying that crustal thinning has been accommodated at upper and lower crustal levels.

\subsubsection{Effects and outreach of late-Variscan extension in the CIZ lower crust: CIMDEF, ALCUDIA, and ESCIN-3.2 sections}

The CIZ is a conflicting area. Although a NI data gap exists in most of the northern CIZ, the CIMDEF autocorrelation profiles (Figs. 1, 9), based on passive source seismic data, show a thick $(\sim 5 \mathrm{~s}$ TWT) lower crust in most of this area (Andrés et al., 2019, 2020). This is in conflict with the NI sections ESCIN-3.2 and northernmost ALCUDIA, where the highly reflective lower crust is less than half as thick (1-2 s TWT). However, granitoids are probably scarce in the Variscan basement sampled by CIMDEF and hidden under the DB (Fig. 1), explaining the prevalence of a thick lower crust. Nevertheless, in and near the ICS batholith, a rather continuous internal reflection in the lower crust could be interpreted as its top part (Figs. 9, 10), thereby indicating that crustal thinning and melting, observed in the surface, has also affected the lower crust (Andrés et al., 2020).

Extension in the northern CIZ occurred simultaneously with shortening in the southwestern Iberian Massif. According to Simancas et al. (2013), this suggests that the tectonic stresses would be dominantly compressional and still induced by ongoing collision. In fact, gravitational instabilities in a thickened crust should mostly be affecting the upper crust. In this context, theoretical models (Royden, 1996; Seyferth and Henk, 2004) indicate that beneath areas of extension in the upper crust, shortening may prevail in the lower crust. This mechanism is an efficient way for syn-convergent exhumation of deep rocks.

Indeed, from a regional tectonic perspective, compression was active till the end of the Variscan Orogeny, and at times, clearly simultaneous with extension $\left(C_{3}\right.$ and $E_{2}$ overlapped in the 315-305 Ma interval; Martínez Catalán et al., 2014). However, it is clear that extension affected the lower crust, as it is thinned in areas of transparent, extended molten upper crust (ESCIN-3.2 and ALCUDIA sections; Figs. 6, 7). Nevertheless, the irregular geometry of the ESCIN-3.2 lower crust might indicate the existence of folds in this reequilibrated layer, witnessing the simultaneity of extension and compression at lower crustal level (Fig. 6). However, we cannot rule out that these undulations represent boudinage (i.e., extension) or Alpine folding, although we consider the latter less likely.

In the ALCUDIA section, the imaged part of the CIZ underwent only moderate upper-crustal shortening (Martínez Poyatos et al., 2012). However, it exhibits a thick laminated lower crust representing pre-Pennsylvanian (most probably pre-Variscan) ductile deformation (Simancas et al., 2013). In addition, the latter appears deformed in two sectors near both ends of the profile, concentrating deformation in discrete structures. The first of them is the very conspicuous crocodile-like structure observed at the southern end and also imaged in the northern part of the IBERSEIS line (Fig. 9b). This structure mimics localized crustal indentation of the OMZ into the CIZ, producing a local underthrusting of the latter to the south that is still (perhaps only partly) preserved. Indentation generated tectonic inversion of the Los Pedroches early-Carboniferous basin (Simancas et al., 2013) and bending of the overlying upper crust, as seen by the uplift of the IRB, both of which predate the imbrication. The Los Pedroches batholith intruded above at 314$304 \mathrm{Ma}$ in an extensional setting (Carracedo et al., 2009), postdating the age of the wedge as no further deformation affected the batholith. This crocodile-like feature probably represents early-Carboniferous Variscan compressional deformation and must account for part of the shortening observed at upper-crustal level.

Contrarily, to the northeast of this section, a ramp-and-flat geometry has been interpreted as a major lower crustal thrust (Martínez Poyatos et al., 2012; Simancas et al., 2013) that helped to compensate for upper and lower crustal shortening. However, the highly reflective lower crust is not repeated in the hanging wall to the structure, so that a subtractive character is a reasonable alternative. As stated above, the thin lower crust to the north of the ramp seems to evidence lower crustal thinning (Fig. 9b), as it underlies an area of uppercrustal extension, the Toledo gneiss dome, characterized by normal faulting and pervasive partial melting (Barbero, 1995; Hernández Enrile, 1991). Regardless of how much shortening that area accommodated during crustal thickening and even though the observed ramp could be a thrust fault reactivated by later extension, the present image of the lower crust 
does not suggests compensation for upper-crustal shortening. However, the lower crust in the ALCUDIA section is anomalously thick elsewhere (up to $6 \mathrm{~s}$ TWT, $18 \mathrm{~km}$ ), suggesting the possibility of important ductile thickening previous to the extension that triggered thinning in its northern part.

\subsubsection{Lower crust signature in southwestern Iberia: the IBERSEIS and southern ALCUDIA sections}

South of the CIZ, the IBERSEIS lower crust reflectivity is also subhorizontal but disrupted by north- and south-dipping features (Fig. 9b). In contrast, these features usually dip to the north in the OMZ, as do the upper-crustal reflections representing Variscan thrusts; in the SPZ, they surprisingly mirror the south-dipping upper-crustal Variscan thrusts. Furthermore, one of these features, placed close to the boundary with the OMZ, affects almost the entire lower crust.

Orogenic orthogonal shortening in the upper crust has been estimated to be $120 \mathrm{~km}(\sim 57 \%)$ for the OMZ and $\sim 80 \mathrm{~km}(\sim 45 \%)$ or even less for the SPZ (Pérez-Cáceres et al., 2016). According to Simancas et al. (2013), the crocodile-like structure and a hypothetical northward subduction of the OMZ might account for this shortening in the OMZ. Similarly, in the SPZ, the lower crustal imbricated structures represent only $\sim 20 \mathrm{~km}$ of shortening so that a detached lower crustal subduction along the OMZ-SPZ might have accommodated the other $60 \mathrm{~km}$.

In this regard, we suggest that the present-day SPZ crustal image represents its decoupled early-Carboniferous extension and later compression. This evolution would have erased any evidence of previous (pre-Carboniferous) subduction and forced the SPZ to thin during extension, i.e., the lower crust had to decrease its thickness ductilely, perhaps first in a more or less distributed way and later through localized shear zones (brittle or not depending on the depth) as it became shallower. However, the upper crust could have preserved most of its original thickness, as the developing basins associated with extension would have been constantly fed by sediments and igneous extrusions and intrusions (like the IRB in the OMZ). Later compression would have folded and thrusted the upper crust and also thickened the lower crust. A few lower crustal normal shear zones might have developed during extension and then been reactivated as ductile thrusts during compression. Those are today observed as south-dipping reflections that disrupt the previous subhorizontal reflectivity in the lower crust and mirror the uppercrustal thrusts. Accordingly, distributed ductile deformation and thrusting might have thickened the lower crust back to its original (or simply stable) thickness in the SPZ, which is something that cannot be quantified but would need to be accounted for when comparing shortening at upper and lower crustal levels. The resulting seismic image of the SPZ would then be that of an extended and then inverted margin, with mirroring reflectors in the upper and lower crust merging in a mid-crustal discontinuity and providing a seismic im- age different to that of a typical foreland thrust and fold belt (e.g., CZ; Fig. 3). This evolution differs from that of a hyperextended magma-rich margin as stretching of the upper and lower crust is not coupled and faults do not cut across the crust and penetrate down into the mantle. In any case, the south-dipping lower crustal reflections, active during the late Carboniferous, postdate subhorizontal reflectivity at the lower crust. It is worth mentioning here that the SPZ seismic image is identical to that of the Rhenohercynian Massif in Germany (Franke et al., 1990; Oncken, 1998), suggesting a similar evolution.

The discussion above shows that the lower crust in the Iberian Massif is thick, except when it is affected by late orogenic extension. The mechanisms that produced lower crustal thickening are probably related to compressional deformation, which is mostly ductile. Continental underthrusting of the CZ underneath the WALZ (Ayarza et al., 1998, 2004) and part of the CIZ (Figs. 6, 9, 10), indentation of the OMZ in the CIZ (Figs. 9, 10), and Variscan thrust-like structures probably played an important role. In addition, the Variscan thrust-like structures help to constrain the age of the subhorizontal reflectivity. Frequent disruption of subhorizontal lower crustal lamination by Variscan (late-Carboniferous) dipping features indicates that the lamination developed prior to Variscan compressional deformation. What this lamination represents is still an open question.

\subsubsection{Origin of the lower crust lamination}

Many vertical incidence seismic reflection profiles worldwide have shown reflective and laminated lower crusts (e.g., Meissner et al., 2006; Wever, 1989) that have often been related to late orogenic extensional events (Meissner, 1989). In the Iberian Massif, surface geology shows that late orogenic extension affects the upper crust, mainly in areas of large previous thickening. However, in contrast to the models from Meissner (1989), important thinning of the lower crust takes place in those areas (ESCIN-3.2 and northern ALCUDIA; Figs. 6, 7, 9). Certainly, lower crustal lamination might come from underplating eased by extension in magma-rich margins (Klemperer et al., 1986). Nevertheless, ductile deformation is also a very likely source of lower crustal lamination. Dipping events observed in the lower crust crosscutting a strong banded reflectivity represent the latest orogenyrelated shortening, which will be further flattened and horizontalized in the next orogeny. Continuous superposition of deformational events at the lower crustal level may decrease the dip of structural/lithological markers and define a subhorizontal fabric. These deformation mechanisms can generate structures with a strong anisotropy, which results in laminated lower crustal fabrics (Carbonell and Smithson, 1991; Okaya et al., 2004). Accordingly, a laminated lower crust may represent an overly reworked lower crust that has been ductilely deformed over several orogenies. In contrast to the model by Meissner (1989), such horizontal reflectivity is ob- 
served along the Iberian Massif in areas where late orogenic extension is absent or weak: the SPZ (Avalonia), the OMZ (peri-Gondwana), the non-extended CIZ, the WALZ, and the CZ (Gondwana). Thus, we suggest that strong lamination in the deep crust is probably a global characteristic of reworked lower crusts not affected by late orogenic extension in the latest orogeny.

\subsection{The Moho and crustal thickness in the Iberian Massif}

The crust-mantle boundary (i.e., the Moho) is basically flat in the Iberian Massif except where affected by Alpine tectonics (Fig. 10). This is rather surprising as the lower crust seems to be quite well preserved, suggesting that the Moho geometry has been flattened out through slow, noninvasive, readjustments.

Flat Mohos imply the existence of isostatic and/or thermal, late to post-orogenic processes that have managed to eliminate crustal roots (Cook, 2002). Northwestern Iberia was affected by late-Carboniferous extension that heated and reworked the CIZ, possibly without significant mantle involvement (Alcock et al., 2009, 2011), but produced crustal thinning (Palomeras et al., 2017: see Moho depth map in Fig. 10). Thick and thermally mature crusts might experience lateral flow of its low-viscosity deeper part that contributes to reduce crustal roots (Seyferth and Henk, 2004). This process might have partly occurred in the CIZ as sampled by the ESCIN-3.2 section (Fig. 6) where an outstanding change in lower crustal thickness and signature exists, manifested by a thinner and very reflective lower crust in contrast to that to the east, in the WALZ ( 1 vs. $3 \mathrm{~s}$ TWT), or to the south, in the ALCUDIA profile (1 vs. 5-6s TWT). In the former, the Variscan crust is still thick even though it experienced lateVariscan extension in its western part and the whole area was slightly affected by Permian and Mesozoic extension, with the latter being linked to the opening of the Bay of Biscay. In fact, underthrusting of the CZ lower crust is still preserved in the eastern CIZ (Figs. 6, 9).

In the southwestern Iberian Massif, a thick laminated lower crust is still observable and the Moho depth is fairly constant $(\sim 10 \mathrm{~s}$ TWT). Carboniferous to Permian isostatic rebound in response to tectonic thickening, erosion, and localized Permian thermal readjustments must have contributed to flatten the Moho. However, seismic reflections show that crustal imbrication into the mantle has locally survived post-orogenic Moho resetting. This indicates that isostatic equilibrium has been reached in a long-wavelength scale, but that local features can still remain if they are supported by the crustal strength and do not pose an isostatic constraint.

\subsection{The (missing) middle crust in the Iberian Massif (and perhaps elsewhere)}

One of the highlights of this work is the lack of a layer that can be identified with a seismic middle crust - but what is the middle crust?

From a metamorphic point of view, the middle crust could be ascribed to the mesozone, which may be correlated with the amphibolite facies whose temperature ranges between $400-500$ and $600-800^{\circ} \mathrm{C}$, with the precise limits depending on the pressure (Spear, 1993). In addition, the epizone, between $200-250$ and $400-500^{\circ} \mathrm{C}$, typically represented by the greenschist facies, is also a metamorphic entity that develops during metamorphism under several kilometers of anchimetamorphic and non-metamorphic rocks. The depths corresponding to these temperature intervals vary with the geothermal gradient. For a Barrowian gradient, typical of a continental crust undergoing collision, the depths for the epizone and mesozone can be estimated to be around 10-20 and 20-30 $( \pm 5) \mathrm{km}$, respectively. Although the boundaries of these metamorphic zones might have a gravity (i.e., density signature), they lack a seismic one. Furthermore, epi-, meso-, and catazonal rocks outcrop everywhere in any eroded orogenic belt, defining a very complex pattern that contrasts with the simplicity of seismic images. This implies that the metamorphic middle crust does not need to coincide with a hypothetic seismic middle crust, with the former often being a part of the upper crust in ancient orogens.

Seismic data are sensitive to velocity and density contrasts but not to the absolute value of velocity and density. If a sharp contrast exists, a reflection appears, but metamorphic zones usually lack sharp boundaries. Thus, from a seismic point of view, a middle crust should be a crustal level bounded in its upper and lower parts by reflections indicative of the existence of important impedance contrasts at its top and bottom. In this regard, only the IRB, intruded between the upper and the lower crust (Carbonell et al., 2004; Simancas et al., 2003) and providing conspicuous velocity contrasts (Palomeras et al., 2009, 2011), fulfills that requirement. However, it is most probably an intrusion emplaced at a mid-crustal discontinuity and does not represent the middle crust.

WA reflection seismic data from the northern Iberian Massif have often resulted in multilayered models despite weak evidence of continuous reflectivity at these levels (Ayarza et al., 1998; Fernández-Viejo et al., 1998, 2000; Pedreira et al., 2003). Even though local velocity contrasts capable of providing weak and patchy reflectivity exist at different crustal depths (e.g., thrust faults and normal detachments may represent lithological boundaries with a noticeable velocity contrast), these are not orogen-scale features but local reflectors. However, many of these reflections have been extrapolated and interpreted as middle crust in seismic WA datasets, despite being part of upper crust when compared with NI data, i.e., lie above the mid-crustal discontinuity (e.g., $V p$ increase at $\sim 10 \mathrm{~km}$ in Fig. 5e). In this regard, the short-wavelength 
heterogeneities of the crust have often been considered by low-resolution WA datasets as laterally continuous features (Levander and Holliger, 1992), something that has led us to incorrect models.

Based on the above, we argue that no seismic middle crust can be identified in the Iberian Massif. In the hinterland, reflectors imaging deformation in the upper crust root in the top of the lower crust. Only in ESCIN-1, which depicts the thin-skinned deformation of the $\mathrm{CZ}$, thrust faults root in a sole thrust and one could argue that the basement underneath these shallow reflections represents the middle crust. However, in the shallower part, to the east, early-Paleozoic and Neoproterozoic sediments occur on both sides of the sole thrust. Moreover, in the deeper parts, to the west, the previous crystalline basement is probably involved in imbrications affecting the upper crust. Thus, in our opinion, nonreflective basement represents the seismic upper crust.

In the Iberian Massif, the Paleozoic was deposited unconformably above Neoproterozoic sediments which could be considered as its basement, but these were not metamorphic then. Only in the OMZ, greenschist to amphibolite facies Neoproterozoic rocks represent the Cadomian basement, but it cannot be distinguished from the overlying Paleozoic metasediments in the NI profiles. An even older crystalline basement of felsic composition exists, as indicated by inherited zircons of 830-2000 Ma age found in Ediacaran orthogneisses, lower-Ordovician volcanics, and Variscan granitoids that resulted from partial melting of such a basement (Fernández-Suárez et al., 1998; Montero et al., 2007; Villaseca et al., 2012). Again, its upper boundary is not imaged on NI profiles. These data also suggest that there are no crustal intervals that can be related to a seismic middle crust in the Iberian Massif. Decoupling of reflectivity (i.e., deformation) at a mid-crustal level led us to define just an upper and a lower crust.

\subsection{Significance of a mid-crustal discontinuity: geometry and lateral extent}

Inspection of the Iberian Massif NI seismic dataset leads us to conclude that an orogenic-scale mid-crustal discontinuity exists. This surface does not always provide a clear reflection, as in the SPZ, but it is clearly defined by the geometry of the upper and lower crustal reflections, asymptotically merging into it. The discontinuity coincides with the top of the lower crust, which is often much more reflective than the upper crust and features a $V p$ increase. Furthermore, this discontinuity has probably acted as a detachment for Variscan deformation in the hinterland of the orogen and in the SPZ. However, in the CZ, the transition between upper and lower crust is poorly defined, as most of its basement was not affected by Variscan tectonics.

Simancas et al. (2013) already described this discontinuity on the basis of the asymptotic geometry of the SPZ faults towards the middle of the crust. These authors concluded that its depth greatly varies when reaching suture boundaries, where the discontinuity roots. Although we do not observe a subduction zone in the reworked elusive suture between the SPZ and the OMZ (Pérez-Cáceres et al., 2015), and we interpret the OMZ-CIZ suture as an indentation between two continental crusts, triggering imbrication into the mantle of the latter (crocodile structure), we agree that this discontinuity would have eased the decoupling of the Iberian crust, allowing subduction of its lower part while the upper part was deformed by folds and thrust faults. In fact, this is clearly observed in the Alpine northward subduction of the Iberian Massif lower crust underneath the CZ (ESCIN-2; Fig. 4) and also, in the Pyrenees, where a detached Iberian lower crust subducts to the north (Teixell et al., 2018). However, in the Iberian Massif, the complexity of Variscan tectonics and late-Variscan crustal re-equilibration has mostly removed evidence of a such mechanisms, although a comparable example has been preserved in the northwest: the thick lower crust imaged by ESCIN-3.3 is interpreted as underthrusting of the CZ lower crust under that of the WALZ (Ayarza et al., 1998; Martínez Catalán et al., 2003, 2012, 2014), even reaching the CIZ, as shown in profile ESCIN-3.2.

Some authors have interpreted the Iberian Massif midcrustal discontinuity as the brittle-ductile transition (e.g., Ehsan et al., 2014; Simancas et al., 2013). Indeed, it bounds a lower crust, highly reflective and ductilely deformed from the upper crust. However, Variscan ductile deformation also occurs above the discontinuity in the entire Iberian Massif, with the exception of the CZ. On the other side, if we deal with present deformation mechanisms, it is unlikely that the brittle-ductile transition, which depends on $\mathrm{P}$ and $\mathrm{T}$ values, coincided with the described discontinuity because (i) it does not necessarily imply an impedance contrast (Litak and Brown, 1989), and (ii) according to Fig. 10, the depth of the discontinuity varies from $4 \mathrm{~s}$ TWT $(\sim 12 \mathrm{~km}$, ALCUDIA section) to $8 \mathrm{~s}$ TWT ( $\sim 21 \mathrm{~km}$, ESCIN-2 section) which would imply unrealistic crustal $P$ and $T$ variations. Accordingly, a different interpretation must be sought.

The Iberian laminated lower crust is probably very old. Granulites dredged in Mesozoic sediments of the Cantabrian margin have yielded ages of up to $1400 \mathrm{Ma}$ (Capdevila et al., 1980, and references therein). Even older Ar-Ar values $(\sim 2500 \mathrm{Ma})$ have been obtained for the Galicia Bank granulites (Gardien et al., 2000). These granulites have been deformed ductilely during several orogenies. However, rocks lying above the lower crust, whatever their nature, are separated from it by a discontinuity that fosters decoupled deformation between both crustal layers. Accordingly, the observed mid-crustal discontinuity probably represents a rheological boundary that separates rocks that have been deformed differently. This boundary, located at the top of the lower crust, represents a velocity increase, as the latter is probably composed of dense granulites and includes relatively abundant basic rocks, which makes it easily identifiable in NI and WA seismic sections. 
The geometry of this discontinuity and its depth, along with that of the Moho (Fig. 10), provide insights into the evolution of the Iberian Massif. Along the southwestern Iberian Massif, the mid-crustal discontinuity is subhorizontal and lies at a depth of between 4 and $6 \mathrm{~s}$ TWT. In the OMZ, the intrusion of the IRB allows one to establish its depth in the top or the bottom of this feature, but, on average, its location would fit the abovementioned values. However, in the center and northwest, the position of the discontinuity varies, deepening down to $8 \mathrm{~s}$ TWT (Figs. 9, 10).

The low-resolution autocorrelation models obtained along the CIMDEF profile show confusing results along the central Iberian Massif. In this region, the mid-crustal discontinuity might lie at 5-6s TWT, deepening around the ICS to $8 \mathrm{~s}$ TWT as it has been affected by pervasive extension and melting, thus defining a thin lower crust $(2 \mathrm{~s}$ TWT, $\sim 6 \mathrm{~km}$; Figs. 9, 10). Accordingly, this feature appears redefined in this area and now follows the geometry of the ICS batholith. The deepening of this discontinuity and associated thinning of the lower crust might have allowed coupled deformation, letting part of the upper crust to the south of the ICS underthrust it (Andrés et al., 2020). This would foster the 400$500 \mathrm{~m}$ topographic change between the northern and southern foreland basins of this Alpine mountain range (Fig. 9). In fact, Simancas et al. (2013) argues that coupled crustal deformation takes place when a relatively weak lower crust exists, which is something that might well represent the context of the ICS. The resulting geometry of this Alpine reactivation and its topographic imprint is different from that observed to the north, in the $\mathrm{CZ}$, where late orogenic extension and melting does not exist and the mid-crustal discontinuity has been preserved.

The most outstanding change in the mid-crustal discontinuity architecture appears in northwestern Iberia, along the ESCIN-3.2 profile. This section features the thinnest crust ( $9 \mathrm{~s}$ TWT) accompanied by the thinnest lower crust ( $\sim 1 \mathrm{~s}$ TWT). The mid-crustal discontinuity lies at $8 \mathrm{~s}$ TWT in contrast to the depth where it appears in the neighboring ESCIN-3-3 and ESCIN-1 lines (6-8 s TWT), suggesting that it has been redefined. Nevertheless, clear reflections root in its upper part, indicating that it still acted as a discontinuity/detachment. Accordingly, we suggest that gravitational collapse followed by crustal melting and extension has thinned the crust in northwestern Iberia (Fig. 10), especially the lower crust, relocating the mid-crustal discontinuity.

Northwestern Iberia was importantly thickened (up to 50$70 \mathrm{~km}$ ) due to the emplacement of the GTMZ allochthonous complexes. Thermal models by Alcock et al. (2009, 2015) show that, as a result, the upper mantle continued increasing its temperature 60-65 Ma after the start of compressional deformation at $360 \mathrm{Ma}$. This implies large thinning of the mantle lithosphere, from 70 to $25-30 \mathrm{~km}$, due to the ascent of the $1300^{\circ} \mathrm{C}$ isotherm. It is not surprising that the lower crust there became highly extended as a consequence of the heat increase, as in the models it reached $800^{\circ} \mathrm{C}$ after $45 \mathrm{Ma}$ and $900{ }^{\circ} \mathrm{C}$ after $55 \mathrm{Ma}$ (315-305 Ma).

\subsubsection{The Iberian Massif Conrad discontinuity}

The idea of a mid-crustal velocity discontinuity was put forward in the 1920s (Conrad, 1925). Early analysis of natural source earthquake recordings and later images from controlled source seismic reflection data provided further evidence that supported a clear distinction between upper and lower crust. This evidence led to the consideration of the Conrad discontinuity as a global-scale feature present in the continental crust. However, this was later challenged as some results of deep seismic reflection profiling did not show a clear distinction between upper and lower crust (Litak and Brown, 1989).

Mid-crustal discontinuities have, however, often been observed in different types of seismic data worldwide (e.g., Fianco et al., 2019; Hobbs et al., 2004; Melekhova et al., 2019; Oncken, 1998; Ross et al., 2004; Snelson et al., 2013). Important changes in the rheology of the crust have also been reported at those depths (Maggini and Caputo, 2020; Wever, 1989), supporting the idea that a mechanical boundary must exist. Thus, we suggest that, even though it is not observed everywhere (Litak and Brown, 1989), this feature is an orogen-scale, world-class continental crustal discontinuity (Artemieva, 2009), often coinciding with the top of the highly laminated lower crust (when there is one). Its existence might determine the way the crust deforms, easing decoupled deformation. Orogenic evolution (e.g., rifting, extension, and melting) may modify it or even erase it; thus, its existence and geometry might help us to understand the geologic history of continents. In this regard, and coming back to the long-forgotten discussion of the nature of the Conrad discontinuity (Conrad, 1925) and its position on top of the laminated lower crust (Wever, 1989), we suggest that, in the Iberian Massif, the observed mid-crustal feature fulfills the characteristics of this debated discontinuity. Its clear signature and regional extension contributes to unraveling its nature and significance.

\section{Conclusions}

Normal incidence seismic data acquired across the Iberian Massif in the last 30 years have provided an entire image of a well-exposed and almost complete part of the European Variscides. Existing gaps in the central part have been recently sampled by passive source seismic recordings (noise and earthquakes) that provide fairly good constraints on the crustal structure.

Results show that crustal thickness varies from $\sim 9 \mathrm{~s}$ TWT in late-Variscan extended areas (northwest of the Central Iberian Zone), to $\sim 10 \mathrm{~s}$ TWT $(30-33 \mathrm{~km})$ in the external South Portuguese Zone, and to $\sim 12 \mathrm{~s}$ TWT $(36-38 \mathrm{~km})$ in 
the internal West Asturian-Leonese Zone. Alpine reactivation has managed to further thicken the crust to at least $\sim 14 \mathrm{~s}$ TWT (42-45 km) in the external Cantabrian Zone and to 35$38 \mathrm{~km}$ in the Iberian Central System, a Tertiary orogenic belt developed in central Spain. The top of an often thick (up to $6 \mathrm{~s}$ TWT) and very reflective lower crust helps to define a mid-crustal discontinuity across the entire Iberian Massif. This boundary represents a level where reflections from the upper and lower crust merge asymptotically, suggesting that it has often acted as a detachment or a decoupling level. Its position and geometry varies mostly in relation to the lateVariscan evolution. Accordingly, it is deeper in northwestern and central Iberia ( $\sim 8 \mathrm{~s}$ TWT), where Variscan crustal thickening was important and gravitational collapse melted and extended the crust, thereby defining a very thin lower crust. However, it appears between 4 and $6 \mathrm{~s}$ TWT to the southwest, where the crust did not thicken as much and its original structure is more well preserved, as it was re-equilibrated later via slow isostasy and erosion.

This discontinuity exists in all the Iberian Massif tectonic zones, regardless of their Gondwana or Avalonia affinity, thereby suggesting it is an orogenic-scale discontinuity. We interpret it as the rheological boundary between an overly ductilely deformed old lower crust and a heterogeneous variably (often also ductilely) deformed upper crust that mostly (but not only) shows evidence of the latest orogenic event. Its geometry, position, and extent match the characteristics defined for the long-forgotten Conrad discontinuity. The identification of similar features in normal incidence profiles worldwide supports its inclusion as a major crustal discontinuity. 


\section{Appendix A: Glossary}

$\begin{array}{ll}\text { CIA: } & \text { Central Iberian Arc } \\ \text { CIZ: } & \text { Central Iberian Zone } \\ \text { CU: } & \text { Central unit } \\ \text { CZ: } & \text { Cantabrian Zone } \\ \text { DB: } & \text { Duero Basin } \\ \text { GTMZ: } & \text { Galicia-Trás-os-Montes Zone } \\ \text { IAA: } & \text { Ibero-Armorican Arc } \\ \text { ICS: } & \text { Iberian Central System } \\ \text { NI: } & \text { Normal incidence } \\ \text { OMA: } & \text { Ossa-Morena Zone } \\ \text { SPZ: } & \text { South Portuguese Zone } \\ \text { TB: } & \text { Tajo Basin } \\ \text { WA: } & \text { Wide angle } \\ \text { WALZ: } & \text { West Asturian-Leonese Zone }\end{array}$


Code availability. GLOBEClaritas commercial seismic data processing software was used to generate the seismic sections displayed in Figs. 3-8.

Data availability. The SeisDARE database includes all data presented here and is available from the Spanish National Research Council repository, DIGITAL.CSIC (https://digital.csic.es/handle/ 10261/101879, DeFelipe et al., 2021).

Author contributions. PA participated in the acquisition of all datasets, developed the main ideas for data interpretation, and wrote the paper. JRMC actively participated in the discussion about the interpretation of the seismic sections and helped to write the paper. AMG reprocessed the seismic sections. JFS participated in funding acquisition and the acquisition of some datasets (IBERSEIS AND ALCUDIA) as well as providing important input in the final discussion. JA supervised the reprocessing of the seismic sections and participated in data acquisition (CIMDEF and ALCUDIA). JA, IP, DM, and IdF participated in the acquisition of some datasets (CIMDEF, ALCUDIA and IBERSEIS) and in parts of the interpretation. CJ participated in funding acquisition and the acquisition and interpretation of some datasets (ESCIN-3 and IBERSEIS). RC led and participated in the acquisition of most of the projects and played an active role in the discussion.

Competing interests. The authors declare that they have no conflict of interest.

Disclaimer. Publisher's note: Copernicus Publications remains neutral with regard to jurisdictional claims in published maps and institutional affiliations.

Special issue statement. This article is part of the special issue "The Iberian Massif in the frame of the European Variscan Belt". It is not associated with a conference.

Acknowledgements. The seismic data were reprocessed using the GLOBEClaritas commercial seismic signal processing software. Funding for this research was provided by the Junta de Castilla y León (grant nos. SA065P17 and SA084P20), the Spanish Ministry of Science and Innovation (grant no. CGL2016-78560-P), and the Generalitat de Catalunya (grant no 2017SGR1022). The comments of Rob Butler and an anonymous reviewer greatly contributed to improving this paper.

Financial support. This research has been supported by the CSIC open-access publication support initiative through its Unit of Information Resources for Research (URICI). Funding for this research was provided by the Junta de Castilla y León (grant nos. SA065P17 and SA084P20), the Spanish Ministry of Science and Innovation (grant no. CGL2016-78560-P), and the Generalitat de Catalunya (grant no 2017SGR1022).

Review statement. This paper was edited by Irene Bianchi and reviewed by Rob Butler and one anonymous referee.

\section{References}

Alcock, J. E., Martínez Catalán, J. R., Arenas, R., and Díez Montes, A.: Use of thermal modeling to assess the tectono-metamorphic history of the Lugo and Sanabria gneiss domes, Northwest Iberia, Bull. Soc. Geol. Fr., 180, 179-197, https://doi.org/10.2113/gssgfbull.180.3.179, 2009.

Alcock, J. E., Martínez Catalán, J. R., and Arenas, R.: Oneand two-dimensional models are equally effective in monitoring the crust's thermal response to advection by large-scale thrusting during orogenesis, Comput. Geosci., 37, 1205-1207, https://doi.org/10.1016/j.cageo.2011.02.012, 2011.

Alcock, J. E., Martínez Catalán, J. R., Rubio Pascual, F. J., Díez Montes, A., Díez Fernández, R., Gómez Barreiro, J., Arenas, R., Dias da Silva, Í., and González Clavijo, E.: 2-D thermal modeling of HT-LP metamorphism in NW and Central Iberia: Implications for Variscan magmatism, rheology of the lithosphere and orogenic evolution, Tectonophysics, 657, 21-37, https://doi.org/10.1016/j.tecto.2015.05.022, 2015.

Alonso, J. L.: Sequences of thrusts and displacement transfer in the superposed duplexes of the Esla Nappe Region (cantabrian zone, nw spain), J. Struct. Geol., 9, 969-983, https://doi.org/10.1016/0191-8141(87)90005-8, 1987.

Alonso, J. L., Marcos, A., and Suárez, A.: Paleogeographic inversion resulting from large out of sequence breaching thrusts: The León Fault (Cantabrian zone, NW Iberia). A new picture of the external Variscan thrust belt in the Ibero-Armorican arc, Geol. Acta, 7, 451-473, https://doi.org/10.1344/105.000001449, 2009.

Álvarez-Marrón, J., Pérez-Estaún, A., Dañobeitia, J. J., Pulgar, J. A., Martínez Catalán, J. R., Marcos, A., Bastida, F., Ayarza, P., Aller, J., Gallart, A., González-Lodeiro, F., Banda, E., Comas, M. C., and Córdoba, D.: Seismic structure of the northern continental margin of Spain from ESCIN deep seismic profiles, Tectonophysics, 264, 153-174, https://doi.org/10.1016/S00401951(96)00124-2, 1996.

Andrés, J., Draganov, D., Schimmel, M., Ayarza, P., Palomeras, I., Ruiz, M., and Carbonell, R.: Lithospheric image of the Central Iberian Zone (Iberian Massif) using globalphase seismic interferometry, Solid Earth, 10, 1937-1950, https://doi.org/10.5194/se-10-1937-2019, 2019.

Andrés, J., Ayarza, P., Schimmel, M., Palomeras, I., Ruiz, M., and Carbonell, R.: What can seismic noise tell us about the Alpine reactivation of the Iberian Massif? An example in the Iberian Central System, Solid Earth, 11, 2499-2513, https://doi.org/10.5194/se-11-2499-2020, 2020.

Arenas, R., Farias, P., Gallastegui, G., Gil Ibarguchi, I., González Lodeiro, F., Klein, E., Marquínez, J., Martín Parra, L. M., Martínez Catalán, J. R., Ortega, E., de Pablo Maciá, J. G., Peinado, M., and Rodriguez Fernández, L. R.: Características geológicas y significado de los dominios que componen la Zona de Galicia-Trás-os- Montes. Simposio sobre Cinturones Orogéni- 
cos, in Simposio sobre Cinturones Orogénicos, II cogreso Geológico de España, SGE, 75-84, 1988.

Arenas, R., Martínez Catalán, J. R., Martínez Sánchez, S., Díaz García, F., Abati, J., Fernández-Suárez, J., Andonaegui, P., and Gómez-Barreiro, J.: Paleozoic ophiolites in the Variscan suture of Galicia (northwest Spain): Distribution, characteristics, and meaning, Mem. Geol. Soc. Am., 200, 425-444, https://doi.org/10.1130/2007.1200(22), 2007.

Artemieva, I.: Continental Crust, Geophysics and Geochemestry, Vol. II - Encyclopedia of Earth and Atmospheric Sciences in the Global Encyclopedia of Life Support Systems, UNESCO, 2009.

Ayarza, P., Martínez Catalán, J. R., Gallart, J., Pulgar, J. A., and Dañobeitia, J. J.: Estudio Sismico de la Corteza Ibérica Norte 3: A seismic image of the Variscan crust in the hinterland of the NW Iberian Massif, Tectonics, 17, 171-186, 1998.

Ayarza, P., Martínez Catalán, J. R., Alvarez-Marrón, J., Zeyen, H., and Juhlin, C.: Geophysical constraints on the deep structure of a limited ocean-continent subduction zone at the North Iberian Margin, Tectonics, 23, TC1010, https://doi.org/10.1029/2002TC001487, 2004.

Azor, A., Lodeiro, F. G., and Simancas, J. F.: Tectonic evolution of the boundary between the Central Iberian and Ossa-Morena zones (Variscan belt, southwest Spain), Tectonics, 13, 45-61, https://doi.org/10.1029/93TC02724, 1994.

Azor, A., Rubatto, D., Simancas, J. F., González Lodeiro, F., Martínez Poyatos, D., Martin Parra, L. M., and Matas, J.: Rheic Ocean ophiolitic remnants in southern Iberia questioned by SHRIMP U-Pb zircon ages on the Beja-Acebuches amphibolites, Tectonics, 27, 1-11, https://doi.org/10.1029/2008TC002306, 2008.

Bandrés, A., Eguíluz, L., Pin, C., Paquette, J. L., Ordóñez, B., Le Fèvre, B., Ortega, L. A., and Gil Ibarguchi, J. I.: The northern Ossa-Morena Cadomian batholith (Iberian Massif): Magmatic arc origin and early evolution, Int. J. Earth Sci., 93, 860-885, https://doi.org/10.1007/s00531-004-0423-6, 2004.

Barbero, L.: Granulite-facies metamorphism in the Anatectic Complex of Toledo, Spain: late Hercynian tectonic evolution by crustal extension, J. Geol. Soc. Lond., 152, 365-382, https://doi.org/10.1144/gsjgs.152.2.0365, 1995.

Birps (British Institutions Reflection Profiling Syndicate) and Ecors (Etude De La Croûte Continentale Et Océanique Par Réflexion Et Réfraction Sismique): Deep seismic reflection profiling between England, France and Ireland, J.-Geol. Soc., 143, 45-52, https://doi.org/10.1144/gsjgs.143.1.0045, 1986.

Bortfeld, R. K.: First results and preliminary interpretation of deepreflection seismic recordings along profile DEKORP 2-South (FRG), J. Geophys.-Z. Geophys., 57, 137-163, 1985.

Braid, J. A., Brendan Murphy, J., Quesada, C., and Mortensen, J.: Tectonic escape of a crustal fragment during the closure of the Rheic Ocean: U-Pb detrital zircon data from the late Palaeozoic Pulo do Lobo and South Portuguese zones, Southern Iberia, J. Geol. Soc. Lond., 168, 383-392, https://doi.org/10.1144/001676492010-104, 2011.

Braid, J. A., Murphy, J. B., Quesada, C., Bickerton, L., and Mortensen, J. K.: Probing the composition of unexposed basement, South Portuguese Zone, southern Iberia: Implications for the connections between the Appalachian and Variscan orogens, Can. J. Earth Sci., 49, 591-613, https://doi.org/10.1139/E11-071, 2012.
Butler, R. W. H. and Mazzoli, S.: Styles of continental contraction: A review and introduction, Spec. Pap. Geol. Soc. Am., 414, 110, https://doi.org/10.1130/2006.2414(01), 2006.

Capdevila, R., Boillot, G., Lepvrier, C., Malod, J. A., and Mascle, G.: Les formations cristallines du Banc Le Danois (marge nordibérique), CR Acad. Sci. Paris, D, 291, 317-320, 1980.

Carbonell, R. and Smithson, S. B.: Large-scale anisotropy within the crust in the Basin and Range province, Geology, 19, 698701, 1991.

Carbonell, R., Simancas, J. F., Juhlin, C., Pous, J., Pérez-Estaún, A., Gonzalez-Lodeiro, F., Munoz, G., Heise, W., and Ayarza, P.: Geophysical evidence of a mantle derived intrusion in SW Iberia, Geophys. Res. Lett., 31, 1-4, 2004.

Carracedo, M., Paquette, J. L., Alonso Olazabal, A., Santos Zalduegui, J. F., de García de Madinabeitia, S., Tiepolo, M., and Gil Ibarguchi, J. I.: U-Pb dating of granodiorite and granite units of the Los Pedroches batholith. Implications for geodynamic models of the southern Central Iberian Zone (Iberian Massif), Int. J. Earth Sci., 98, 1609-1624, https://doi.org/10.1007/s00531-0080317-0, 2009.

Carvalho, D.: The metallogenetic consequences of plate tectonics and the upper Paleozoic evolution of southern Portugal, Estud. Notas e Trab. S. F. M., Servico de Fomento Mineiro, 20, $297-$ 320, 1972.

Casquet, C., Galindo, C., Tornos, F., Velasco, F., and Canales, A.: The Aguablanca $\mathrm{Cu}-\mathrm{Ni}$ ore deposit (Extremadura, Spain), a case of synorogenic orthomagmatic mineralization: Age and isotope composition of magmas (Sr, Nd) and ore (S), Ore Geol. Rev., 18, 237-250, https://doi.org/10.1016/S0169-1368(01)00033-6, 2001.

Chopra, S. and Alexeev, V.: Application of texture attribute analysis to 3D seismic data, Soc. Explor. Geophys. - 75th SEG Int. Expo. Annu. Meet. SEG 2005, 30, 767-770, https://doi.org/10.1190/1.2144439, 2005.

Conrad, V.: Laufzeitkurven des Tauernbens vom 28, Mitt. Erdb. Komm. WIen Akad. Wiss., 59, 1-23, 1925.

Cook, F. A.: Fine structure of the continental reflection Moho, Bull. Geol. Soc. Am., 114, 64-79, https://doi.org/10.1130/00167606(2002)114<0064:FSOTCR>2.0.CO;2, 2002.

Corretgé, L. G. and Suárez, O.: Cantabrian and Palentian Zones. Igneous Rocks, in: Pre-Mesozoic Geology of Iberia, edited by: Dallmeyer, R. D. and Martínez García, E., Springer-Verlag, Berlin, 72-79, 1990.

Dallmeyer, R. D. and Quesada, C.: Cadomian vs. Variscan evolution of the Ossa-Morena zone (SW Iberia): field and 40Ar/39Ar mineral age constraints, Tectonophysics, 216, 339364, https://doi.org/10.1016/0040-1951(92)90405-U, 1992.

Dallmeyer, R. D., Martínez Catalán, J. R., Arenas, R., Gil Ibarguchi, J. I., Gutiérrez-Alonso, G., Farias, P., Bastida, F., and Aller, J.: Diachronous Variscan tectonothermal activity in the NW Iberian Massif: Evidence from ${ }^{40} \mathrm{Ar} /{ }^{39} \mathrm{Ar}$ dating of regional fabrics, Tectonophysics, 277, 307-337, https://doi.org/10.1016/S00401951(97)00035-8, 1997.

DeFelipe, I., Pedreira, D., Pulgar, J. A., van der Beek, P. A., Bernet, M., and Pik, R.: Unraveling the Mesozoic and Cenozoic Tectonothermal Evolution of the Eastern Basque-Cantabrian Zone-Western Pyrenees by LowTemperature Thermochronology, Tectonics, 38, 3436-3461, https://doi.org/10.1029/2019TC005532, 2019. 
DeFelipe, I., Alcalde, J., Ivandic, M., Martí, D., Ruiz, M., Marzán, I., Diaz, J., Ayarza, P., Palomeras, I., Fernandez-Turiel, J.-L., Molina, C., Bernal, I., Brown, L., Roberts, R., and Carbonell, R.: Reassessing the lithosphere: SeisDARE, an open-access seismic data repository, Earth Syst. Sci. Data, 13, 1053-1071, https://doi.org/10.5194/essd-13-1053-2021, 2021.

DEKORP Research Group: Results of deep reflection seismic profiling in the Oberpfalz (Bavaria), Geophys. J. R. Astron. Soc., 89, 353-360, https://doi.org/10.1111/j.1365-246X.1987.tb04430.x, 1987.

de Vicente, G., Giner, J. L., Muñoz-Martí, A., González-Casado, J. M., and Lindo, R.: Determination of present-day stress tensor and neotectonic interval in the Spanish Central System and Madrid Basin, central Spain, Tectonophysics, 266, 405-424, https://doi.org/10.1016/S0040-1951(96)00200-4, 1996.

Dias, R. and Ribeiro, A.: The Ibero-Armorican Arc: A collision effect against an irregular continent?, Tectonophysics, 246, 113128, https://doi.org/10.1016/0040-1951(94)00253-6, 1995.

Díaz Azpiroz, M., Fernández, C., Castro, A., and El-Biad, M.: Tectonometamorphic evolution of the Aracena metamorphic belt (SW Spain) resulting from ridge-trench interaction during Variscan plate convergence, Tectonics, 25, 1-20, https://doi.org/10.1029/2004TC001742, 2006.

Díez Balda, M. A., Martínez Catalán, J. R., and Ayarza, P.: Syncollisional extensional collapse parallel to the orogenic trend in a domain of steep tectonics: the Salamanca Detachment Zone (Central Iberian Zone, Spain), J. Struct. Geol., 17, 163-182, https://doi.org/10.1016/0191-8141(94)E0042-W, 1995.

Díez Montes, A., Martínez Catalán, J. R., and Bellido Mulas, F.: Role of the Ollo de Sapo massive felsic volcanism of NW Iberia in the Early Ordovician dynamics of northern Gondwana, Gondwana Res., 17, 363-376, https://doi.org/10.1016/j.gr.2009.09.001, 2010.

Ehsan, S. A., Carbonell, R., Ayarza, P., Martí, D., PérezEstaún, A., Martínez-Poyatos, D. J., Simancas, J. F., Azor, A., and Mansilla, L.: Crustal deformation styles along the reprocessed deep seismic reflection transect of the Central Iberian Zone (Iberian Peninsula), Tectonophysics, 621, 159-174, https://doi.org/10.1016/j.tecto.2014.02.014, 2014.

Ehsan, S. A., Carbonell, R., Ayarza, P., Martí, D., Martínez Poyatos, D., Simancas, J. F., Azor, A., Ayala, C., Torné, M., and Pérez-Estaún, A.: Lithospheric velocity model across the Southern Central Iberian Zone (Variscan Iberian Massif): The ALCUDIA wide-angle seismic reflection transect, Tectonics, 34, 535554, https://doi.org/10.1002/2014TC003661, 2015.

Expósito, I., Simancas, J. F., and Lodeiro, F. G.: Estructura de la mitad septentrional de la zona de Ossa-Morena: Deformación en el bloque inferior de un cabalgamiento cortical de evolución compleja: Deformación en el bloque inferior de un cabalgamiento cortical de evolución compleja, Rev. la Soc. Geológica España, 15, 3-14, 2002.

Expósito, I., Simancas, J. F., González Lodeiro, F., Bea, F., Montero, P., and Salman, K.: Metamorphic and deformational imprint of Cambrian - Lower Ordovician rifting in the Ossa-Morena Zone (Iberian Massif, Spain), J. Struct. Geol., 25, 2077-2087, https://doi.org/10.1016/S0191-8141(03)00075-0, 2003.

Farias, P., Gallastegui, G., González Lodeiro, F., Marquinez, J., Martín-Parra, L. M., Martínez Catalán, J. R., and Pablo-Maciá, J. G.: "Aportaciones al conocimiento de la litoestratigrafia y es- tructura de Galicia Central”, Memórias da Fac. Ciências, Univ. do Porto, 1, 411-431, 1987.

Fernández-Suárez, J., Gutiérrez-Alonso, G., Jenner, G. A., and Jackson, S. E.: Geochronology and geochemistry of the Pola de Allande granitoids (northern Spain): their bearing on the Cadomian-Avalonian evolution of northwest Iberia, Can. J. Earth Sci., 35, 1439-1453, https://doi.org/10.1139/cjes-35-12-1439, 1998.

Fernández-Viejo, G., Gallart, J., Pulgar, J. A., Gallastegui, J., Dañobeitia, D., and Córdoba, D.: Crustal transition between continental and oceanico domains along the North Iberian margin from wide angle seismic and gravity data, Geophys. Res. Lett., 25, 4249-4252, 1998.

Fernández-Viejo, G., Gallart, J., Pulgar, A., Córdoba, D., and Dañobeitia, J. J.: Seismic signature of Variscan and Alpine tectonics in NW Iberia: Crustal structure of the Cantabrian Mountains and Duero Basin, J. Geophys. Res., 105, 3001-3018, 2000.

Fianco, C. B., França, G. S., Albuquerque, D. F., Vilar, C. da S., and Argollo, R. M.: Using the receiver function for studying earth deep structure in the Southern Borborema Province, J. South Am. Earth Sci., 94, 102221, https://doi.org/10.1016/j.jsames.2019.102221, 2019.

Finlayson, D. M., Collins, C. D. N., and Lock, J.: Pwave velocity features of the lithosphere under the Eromanga Basin, Eastern Australia, including a prominent MIDcrustal (Conrad?) discontinuity, Tectonophysics, 101, 267-291, https://doi.org/10.1016/0040-1951(84)90117-3, 1984.

Flecha, I., Palomeras, I., Carbonell, R., Simancas, J. F., Ayarza, P., Matas, J., González-Lodeiro, F., and PérezEstaún, A.: Seismic imaging and modelling of the lithosphere of SW-Iberia, Tectonophysics, 472, 148-157, https://doi.org/10.1016/j.tecto.2008.05.033, 2009.

Franke, W.: The mid-European segment of the Variscides: Tectonostratigraphic units, terrane boundaries and plate tectonic evolution, Geol. Soc. Spec. Publ., 179, 35-56, https://doi.org/10.1144/GSL.SP.2000.179.01.05, 2000.

Franke, W., Bortfeld, R. K., Brix, M., Drozdzewski, G., Dürbaum, H. J., Giese, P., Janoth, W., Jödicke, H., Reichert, C., Scherp, A., Schmoll, J., Thomas, R., Thünker, M., Weber, K., Wiesner, M. G., and Wong, H. K.: Crustal structure of the Rhenish Massif: results of deep seismic reflection lines Dekorp 2-North and 2-North-Q, Geol. Rundschau, 79, 523-566, https://doi.org/10.1007/BF01879201, 1990.

Gallastegui, J., Pulgar, J. A., and Alvarez-Marrón, J.: 2-D seismic modeling of the Variscan foreland thrust and fold belt crust in NW Spain from ESCIN-1 deep seismic reflection data, Tectonophysics, 269, 21-32, https://doi.org/10.1016/S00401951(96)00166-7, 1997.

Gallastegui, J., Pulgar, J. A., and Gallart, J.: Alpine tectonic wedging and crustal delamination in the Cantabrian Mountains (NW Spain), Solid Earth, 7, 1043-1057, https://doi.org/10.5194/se-71043-2016, 2016.

García Casquero, J. L., Boelrijk, N. A. I. M., Chacón, J., and Priem, H. N. A.: Rb-Sr evidence for the presence of Ordovician gsranites in the deformed basement of the BadajozCórdoba belt, SW Spain, Geol. Rundschau, 74, 379-384, https://doi.org/10.1007/BF01824904, 1985.

Gardien, V., Arnaud, N., and Desmurs, L.: Petrology and arar dating of granulites from the galicia bank (spain): African 
craton relics in western europe, Geodin. Acta, 13, 103-117, https://doi.org/10.1080/09853111.2000.11105367, 2000.

Gómez-Pugnaire, M. T., Azor, A., Fernández-Soler, J. M., and López Sánchez-Vizcaíno, V.: The amphibolites from the OssaMorena/Central Iberian Variscan suture (Southwestern Iberian Massif): Geochemistry and tectonic interpretation, Lithos, 68, 23-42, https://doi.org/10.1016/S0024-4937(03)00018-5, 2003.

Gómez Barreiro, J., Martínez Catalán, J. R., Arenas, R., Castiñeiras, P., Abati, J., Díaz García, F., and Wijbrans, J. R.: Tectonic evolution of the upper allochthon of the Órdenes complex (northwestern Iberian Massif): Structural constraints to a polyorogenic peri-Gondwanan terrane, Geol. Soc. Am. Spec. Pap., 423, 315332, https://doi.org/10.1130/2007.2423(15), 2007.

Hernández Enrile, J. L.: Extensional tectonics of the toledo ductilebrittle shear zone, central Iberian Massif, Tectonophysics, 191, 311-324, https://doi.org/10.1016/0040-1951(91)90064-Y, 1991.

Hobbs, B. E., Ord, A., Regenauer-Lieb, K., and Drummond, B.: Fluid reservoirs in the crust and mechanical coupling between the upper and lower crust, Earth, Planets Sp., 56, 1151-1161, https://doi.org/10.1186/BF03353334, 2004.

Julivert, M., Fontboté, M., Ribeiero, A., and Conde, L. E.: Mapa tectónico de la Península Ibérica y Baleares Notas Incluye mapa: Unidades estructurales de la Península Ibérica, Escala 1: 1000 000, Instituto Geológico y Minero de España, 1972.

Klemperer, S. L., Hauge, T. A., Hauser, E. C., Oliver, J. E., and Potter, C. J.: The Moho in the northern Basin and Range Province, Nevada, along the COCORP $40^{\circ} \mathrm{N}$ seismic- reflection transect, Geol. Soc. Am. Bull., 97, 603-618, https://doi.org/10.1130/00167606(1986)97<603:TMITNB>2.0.CO;2, 1986.

Kossmat, F.: Gliederung des varistischen Gebirgsbaues. Abhandlungen des Sächsischen, in: Abhandlungen des Sächsischen Geologuschen Landesamts, edited by: des S. G. Landesamts, A., Leipzig, Heft 1, 1-39, 1927.

Levander, A. R. and Holliger, K.: Small-scale heterogeneity and large-scale velocity structure of the continental crust, J. Geophys. Res., 97, 8797-8804, https://doi.org/10.1029/92JB00659, 1992.

Linnemann, U., Pereira, M. F., Jeffries, T. E., Drost, K., and Gerdes, A.: The Cadomian Orogeny and the opening of the Rheic Ocean: The diacrony of geotectonic processes constrained by LA-ICPMS U-Pb zircon dating (Ossa-Morena and Saxo-Thuringian Zones, Iberian and Bohemian Massifs), Tectonophysics, 461, 21-43, https://doi.org/10.1016/j.tecto.2008.05.002, 2008.

Litak, R. K. and Brown, L. D.: A modern perspective on the Conrad Discontinuity, Eos, Trans. Am. Geophys. Union, 70, 713-725, https://doi.org/10.1029/89EO00223, 1989.

López Sánchez-Vizcaíno, V., Gómez-Pugnaire, M. T., Azor, A., and Fernández-Soler, J. M.: Phase diagram sections applied to amphibolites: A case study from the Ossa-Morena/Central Iberian Variscan suture (Southwestern Iberian Massif), Lithos, 68, 1-21, https://doi.org/10.1016/S0024-4937(03)00017-3, 2003.

Lotze, F.: Stratigraphie und Tektonik des Keltiberischen Grundgebirges (Spanien), Abhandlungen Gesellschaft der Wissenschaften zu Göttingen, Abhandlungen der Gesellschaft der Wissenschaften in Göttingen, Mathematisch-Physikalische Klasse, 14, 143-162, 1929.

Maggini, M. and Caputo, R.: Sensitivity analysis for crustal rheological profiles: Examples from the Aegean region, Ann. Geophys., 63, 1-29, https://doi.org/10.4401/ag-8244, 2020.
Martínez Catalán, J. R.: Are the oroclines of the Variscan belt related to late Variscan strike-slip tectonics?, Terra Nov., 23, 241247, https://doi.org/10.1111/j.1365-3121.2011.01005.x, 2011.

Martínez Catalán, J. R.: The Central Iberian arc, an orocline centered in the Iberian Massif and some implications for the Variscan belt, Int. J. Earth Sci., 101, 1299-1314, https://doi.org/10.1007/s00531-011-0715-6, 2012.

Martínez Catalán, J. R., Ayarza, P., Pulgar, J. A., Pérez-Estaún, A., Gallart, J., Marcos, A., Bastida, F., Álvarez-Marrón, J., González Lodeiro, F., Aller, J., Dañobeitia, J. J., Banda, E., Córdoba, D., and Comas, M. C.: Results from the ESCIN-N3.3 marine deep seismic profile along the Cantabrian continental margin, Rev. Soc. Geol. España, 8, 341-354, 1995.

Martínez Catalán, J. R., Fernández-Suárez, J., Jenner, G. A., Belousova, E., and Díez Montes, A.: Provenance constraints from detrital zircon $\mathrm{U}-\mathrm{Pb}$ ages in the NW Iberian Massif: implications for Palaeozoic plate configuration and Variscan evolution, J. Geol. Soc. Lond., 161, 463-476, https://doi.org/10.1144/0016764903-054, 2004.

Martínez Catalán, J. R., Arenas, R., Díagarcía, F., González Cuadra, P., Gómez-Barreiro, J., Abati, J., Castiñeiras, P., FernándezSuárez, J., Sánchez Martínez, S., Andonaegui, P., González Clavijo, E., Díez Montes, A., Rubio Pascual, F. J., and Valle Aguado, B.: Space and time in the tectonic evolution of the northwestern Iberian Massif: Implications for the Variscan belt, Mem. Geol. Soc. Am., 200, 403-423, https://doi.org/10.1130/2007.1200(21), 2007.

Martínez Catalán, J. R., Álvarez Lobato, F., Pinto, V., Gómez Barreiro, J., Ayarza, P., Villalaín, J. J., and Casas, A.: Gravity and magnetic anomalies in the allochthonous rdenes Complex (Variscan belt, northwest Spain): Assessing its internal structure and thickness, Tectonics, 31, 1-18, https://doi.org/10.1029/2011TC003093, 2012.

Martínez Catalán, J. R., Rubio Pascual, F. J., Díez Montes, A., Díez Fernández, R., Gómez Barreiro, J., Dias da Silva, Í., González Clavijo, E., Ayarza, P., and Alcock, J. E.: The late Variscan HT/LP metamorphic event in NW and Central Iberia: relationships to crustal thickening, extension, orocline development and crustal evolution, Geol. Soc. Lond. Spec. Publ., 405, 225-247, https://doi.org/10.1144/SP405.1, 2014.

Martínez Catalán, J. R., Díez Balda, M. A., Escuder Viruete, J., Villar Alonso, P., Ayarza, P., Gonalez Clavijo, E., and Dïez Montes, A.: Cizallamientos dúctiles de escala regional en la provincia de Salamanca, in: Geo-Guias: Rutas Geológicas por la Península Ibérica, Canarias, Sicilia y Marruecos, edited by: Diaz Azpiroz, M., Exposito Ramos, I., Llana Fúnez, S., and Bauluz Lázaro, B., Sociedad Geológica de España, 109-118, 2019.

Martínez García, A.: Seismic characterization and geodynamic significane of the mid-crustal discontinuity across the Variscan Iberia, Universidad de Barcelona, Master Th., 31 pp., 2019.

Martínez García, E.: El Paleozoico de la Zona Cantabrica Oriental (Noroeste de España), Trab. Geol., 11, 95-127, 1981.

Martínez Poyatos, D., Carbonell, R., Palomeras, I., Simancas, J. F., Ayarza, P., Martí, D., Azor, A., Jabaloy, A., González Cuadra, P., Tejero, R., Martín Parra, L. M., Matas, J., González Lodeiro, F., Pérez-Estaún, A., García Lobón, J. L., and Mansilla, L.: Imaging the crustal structure of the Central Iberian Zone (Variscan Belt): The ALCUDIA deep seismic reflection transect, Tectonics, 31, 1-21, https://doi.org/10.1029/2011TC002995, 2012. 
Martínez Poyatos, D. J.: Estructura del borde meridional de la Zona Centroibérica y su relación con el contacto entre las Zonas Centroibérica y de Ossa-Morena, in: Serie Nova Terra, 18, edited by: de Laxe, L. X., Instituto Universitario de Xeoloxía, A Coruña, Spain, p. 295, 2002.

Matte, P.: The Variscan collage and orogeny (480-290 Ma) and the tectonic definition of the Armorica microplate: a review - Matte - 2003 - Terra Nova - Wiley Online Library, Terra Nov., 13, 122-128, 2001.

Matte, P. and Ribeiro, A.: Forme et orientation de l'ellipsoïde de déformation dans la virgation hercynienne de Galice, Relations avec le plissement et hypothèses sur la genèse de l'arc ibéroarmoricain, Comptes Rendus l'Académie des Sci, 280, 28252828, 1975.

Meissner, R.: Rupture, creep, lamellae and crocodiles: happenings in the continental crust, Terra Nov., 1, 17-28, https://doi.org/10.1111/j.1365-3121.1989.tb00321.x, 1989.

Meissner, R., Rabbel, W., and Kern, H.: Seismic lamination and anisotropy of the lower continental crust, Tectonophysics, 416, 81-99, https://doi.org/10.1016/j.tecto.2005.11.013, 2006.

Melekhova, E., Schlaphorst, D., Blundy, J., Kendall, J. M., Connolly, C., McCarthy, A., and Arculus, R.: Lateral variation in crustal structure along the Lesser Antilles arc from petrology of crustal xenoliths and seismic receiver functions, Earth Planet. Sc. Lett., 516, 12-24, https://doi.org/10.1016/j.epsl.2019.03.030, 2019.

Montero, P., Bea, F., González-Lodeiro, F., Talavera, C., and Whitehouse, M. J.: Zircon ages of the metavolcanic rocks and metagranites of the Ollo de Sapo Domain in central Spain: Implications for the Neoproterozoic to Early Palaeozoic evolution of Iberia, Geol. Mag., 144, 963-976, https://doi.org/10.1017/S0016756807003858, 2007.

Ochsner, A.: U-Pb geochronology of the Upper Proterozoic-Lower Paleozoic geodynamic evolution in the Ossa-Morena Zone (SW Iberia): constraints on the timing of the Cadomian orogeny, University of Zurich, Diss. ETH10, PhD, 192, 261 pp., 1993.

Okaya, D., Rabbel, W., Beilecke, T., and Hasenclever, J.: P wave material anisotropy of a tectono-metamorphic terrane: An active source seismic experiment at the KTB super-deep drill hole, southeast Germany, Geophys. Res. Lett., 31, 1-4, https://doi.org/10.1029/2004GL020855, 2004.

Oliveira, J. T.: Part VI: South Portuguese Zone, stratigraphy and synsedimentary tectonism, in: Pre-Mesozoic Geology of Iberia, edited by: Dallmeyer, R. D. and Martínez García, E., Springer, Berlin, Germany, 334-347, 1990.

Oncken, O.: Orogenic mass transfer and reflection seismic patterns - Evidence from DEKORP sections across the European variscides (central Germany), Tectonophysics, 286, 47-61, https://doi.org/10.1016/S0040-1951(97)00254-0, 1998.

Palomeras, I., Carbonell, R., Flecha, I., Simancas, J. F., Ayarza, P., Matas, J., Poyatos, D. M., Azor, A., Lodeiro, F. G., and PérezEstaún, A.: Nature of the lithosphere across the Variscan orogen of SW Iberia: Dense wide-angle seismic reflection data, J. Geophys. Res.-Sol. Ea., 114, 1-29, 2009.

Palomeras, I., Carbonell, R., Ayarza, P., Martí, D., Brown, D., and Simancas, J. F.: Shear wave modeling and Poisson's ratio in the Variscan Belt of SW Iberia, Geochem. Geophy. Geosy., 12, 1-23, https://doi.org/10.1029/2011GC003577, 2011.
Palomeras, I., Villaseñor, A., Thurner, S., Levander, A., Gallart, J., and Harnafi, M.: Lithospheric strcuture of Iberia and Morocco using finite-frequency Rayleigh wave tomogrpahy from earthquakes and seismic ambient noise, Geochem. Geophy. Geosy., 18, 1824-1840, https://doi.org/10.1002/2016GC006657, 2017.

Palomeras, I., Ayarza, P., Andrés, J., Álvarez-Valero, A., GómezBarreiro, J., Díaz, J., Alcalde, J., and Carbonell, R.: Mapping and Interpreting the Uppermost Mantle Reflectivity Beneath Central and South-West Iberia, J. Geophys. Res.-Sol. Ea., 126, e2020JB019987, https://doi.org/10.1029/2020JB019987, 2021.

Pedreira, D., Pulgar, J. A., Gallart, J., and Díaz, J.: Seismic evidence of Alpine crustal thickening and wedging from the western Pyrenees to the Cantabrian Mountains (north Iberia), J. Geophys. Res., 108, 1-21, https://doi.org/10.1029/2001JB001667, 2003.

Pereira, M. F., Ribeiro, C., Vilallonga, F., Chichorro, M., Drost, K., Silva, J. B., Albardeiro, L., Hofmann, M., and Linnemann, U.: Variability over time in the sources of South Portuguese Zone turbidites: Evidence of denudation of different crustal blocks during the assembly of Pangaea, Int. J. Earth Sci., 103, 1453-1470, https://doi.org/10.1007/s00531-013-0902-8, 2014.

Pérez-Cáceres, I., Martínez Poyatos, D., Simancas, J. F., and Azor, A.: The elusive nature of the Rheic Ocean suture in SW Iberia, Tectonics, 34, 2429-2450, https://doi.org/10.1002/2015TC003947, 2015.

Pérez-Cáceres, I., Simancas, J. F., Martínez Poyatos, D., Azor, A., and González Lodeiro, F.: Oblique collision and deformation partitioning in the SW Iberian Variscides, Solid Earth, 7, 857-872, https://doi.org/10.5194/se-7-857-2016, 2016.

Pérez-Estaún, A., Bastida, F., Alonso, J. L., Marquínez, J., Aller, J., Alvarez-Marrón, J., Marcos, A., and Pulgar, J. A.: A thinskinned tectonics model for an arcuate fold and thrust belt: The Cantabrian Zone (Variscan Ibero-Armorican Arc), Tectonics, 7, 517-537, https://doi.org/10.1029/TC007i003p00517, 1988.

Pérez-Estaún, A., Bastida, F., Martínez Catalán, J.R. Gutierrez Marco, J. C., Marcos, A., and Pulgar, J.: West Asturian-Leonese Zone. Stratigraphy, in: Pre-Mesozoic Geology of Iberia, edited by: Dallmeyer, R. D. and Martínez Garcia, E., Springer-Verlag, Berlin, 92-102, 1990.

Pérez-Estaún, A., Martínez Catalán, J. R., and Bastida, F.: Crustal thickening and deformation sequence in the footwall to the suture of the Variscan belt of northwest Spain, Tectonophysics, 191, 243-253, https://doi.org/10.1016/0040-1951(91)90060-6, 1991.

Pérez-Estaún, A., Pulgar, J. A., Banda, E., and Alvarez-Marrón, J.: Crustal structure of the external variscides in northwest spain from deep seismic reflection profiling, Tectonophysics, 232, 91118, https://doi.org/10.1016/0040-1951(94)90078-7, 1994.

Pin, C., Fonseca, P. E., Paquette, J. L., Castro, P., and Matte, P.: The ca. 350 Ma Beja Igneous Complex: A record of transcurrent slab break-off in the Southern Iberia Variscan Belt?, Tectonophysics, 461, 356-377, https://doi.org/10.1016/j.tecto.2008.06.001, 2008.

Pulgar, J. A., Gallart, J., Fernández-Viejo, G., Pérez-Estaún, A., and Álvarez-Marrón, J.: Seismic image of the Cantabrian Mountains in the western extension of the Pyrenees from integrated ESCIN reflection and refraction data, Tectonophysics, 264, 1-19, https://doi.org/10.1016/S0040-1951(96)00114-X, 1996.

Quesada, C. and Dallmeyer, R. D.: Tectonothermal evolution of the Badajoz-Cordóba shear zone (SW Iberia): characteristics and ${ }^{40} \mathrm{Ar} /{ }^{39} \mathrm{Ar}$ mineral age constraints, Tectonophysics, 231, 195213, https://doi.org/10.1016/0040-1951(94)90130-9, 1994. 
Quintana, L., Pulgar, J. A., and Alonso, J. L.: Displacement transfer from borders to interior of a plate: A crustal transect of Iberia, Tectonophysics, 663, 378-398, https://doi.org/10.1016/j.tecto.2015.08.046, 2015.

Rat, P.: The Basque-Cantabrian basin between the Iberian and European plates: Some facts but still many problems, Rev. Soc. Geológica España, 1, 327-348, 1988.

Reche, J., Martinez, F. J., Arboleya, M. L., Dietsch, C., and Briggs, W. D.: Evolution of a kyanite-bearing belt within a HT-LP orogen: the case of NW Variscan Iberia, J. Metamorph. Geol., 16, 379-394, https://doi.org/10.1111/j.1525-1314.1998.00142.x, 1998.

Robardet, M.: Alternative approach to the Variscan Belt in southwestern Europe: Preorogenic paleobiogeographical constraints, Spec. Pap. Geol. Soc. Am., 364, 1-15, https://doi.org/10.1130/08137-2364-7.1, 2002.

Robardet, M. and Gutiérrez Marco, J. C.: Ossa-Morena Zone. Stratigraphy. Passive Margin Phase (Ordovician-SilurianDevonian), in: Pre-Mesozoic Geology of Iberia, edited by: Dallmeyer, R. D. and Martínez García, E., Springer-Verlag, Berlin, 267-272, 1990.

Rodrigues, B., Chew, D. M., Jorge, R. C. G. S., Fernandes, P., VeigaPires, C., and Oliveira, J. T.: Detrital zircon geochronology of the Carboniferous Baixo Alentejo Flysch Group (South Portugal); Constraints on the provenance and geodynamic evolution of the South Portuguese Zone, J. Geol. Soc. London., 172, 294-308, https://doi.org/10.1144/jgs2013-084, 2015.

Ross, A. R., Brown, L. D., Pananont, P., Nelson, K. D., Klemperer, S. L., Haines, S., Wenjin, Z., and Jingru, G.: Deep reflection surveying in central Tibet: Lower-crustal layering and crustal flow, Geophys. J. Int., 156, 115-128, https://doi.org/10.1111/j.1365246X.2004.02119.x, 2004.

Royden, L.: Coupling and decoupling of crust and mantle in convergent orogens: Implications for strain partitioning in the crust, J. Geophys. Res., 101, 17679-17705, 1996.

Rubio Pascual, F. J., Arenas, R., Martínez Catalán, J. R., Rodríguez Fernández, L. R., and Wijbrans, J. R.: Thickening and exhumation of the Variscan roots in the Iberian Central System: Tectonothermal processes and ${ }^{40} \mathrm{Ar} /{ }^{39} \mathrm{Ar}$ ages, Tectonophysics, 587, 207-221, https://doi.org/10.1016/j.tecto.2012.10.005, 2013.

Sánchez de Posada, L. C., Martínez Chacón, M. L., Méndez Fernández, C., Menéndez Alvarez, J. R. Truyols, J., and Villa, E.: Carboniferous Pre-Stephanian rocks of the Asturian-Leonese Domain (Cantabrian Zone), in: Pre-Mesozoic Geology of Iberia, edited by: Dallmeyer, R. D. and Martínez García, E., SpringerVerlag, 24-33, 1990.

Sánchez-García, T., Quesada, C., Bellido, F., Dunning, G. R., and González del Tánago, J.: Two-step magma flooding of the upper crust during rifting: The Early Paleozoic of the Ossa Morena Zone (SW Iberia), Tectonophysics, 461, 72-90, https://doi.org/10.1016/j.tecto.2008.03.006, 2008.

Sánchez-García, T., Bellido, F., Pereira, M. F., Chichorro, M., Quesada, C., Pin, C., and Silva, J. B.: Rift-related volcanism predating the birth of the Rheic Ocean (OssaMorena zone, SW Iberia), Gondwana Res., 17, 392-407, https://doi.org/10.1016/j.gr.2009.10.005, 2010.

Sánchez Martínez, S., Arenas, R., Andonaegui, P., Martínez Catalán, J. R., and Pearce, J. A.: Geochemistry of two associated ophiolites from the Cabo Ortegal Complex (Variscan belt of NW Spain), Mem. Geol. Soc. Am., 200, 445-467, https://doi.org/10.1130/2007.1200(23), 2007.

Schmelzbach, C., Juhlin, C., Carbonell, R., and Simancas, J. F.: Prestack and poststack migration of crooked-line seismic reflection data: A case study from the South Portuguese Zone fold belt, southwestern Iberia, Geophysics, 72, 9-18, https://doi.org/10.1190/1.2407267, 2007.

Schmelzbach, C., Simancas, J. F., Juhlin, C., and Carbonell, R.: Seismic reflection imaging over the South Portuguese Zone foldand-thrust belt, SW Iberia, J. Geophys. Res.-Sol. Ea., 113, 1-16, https://doi.org/10.1029/2007JB005341, 2008.

Seyferth, M. and Henk, A.: Syn-convergent exhumation and lateral extrusion in continental collision zones - Insights from three-dimensional numerical models, Tectonophysics, 382, 1-29, https://doi.org/10.1016/j.tecto.2003.12.004, 2004.

Shelley, D. and Bossière, G.: A new model for the Hercynian Orogen of Gondwanan France and Iberia, J. Struct. Geol., 22, 757776, https://doi.org/10.1016/S0191-8141(00)00007-9, 2000.

Simancas, J. F., Martínez Poyatos, D., Expósito, I., Azor, A., and González Lodeiro, F.: The structure of a major suture zone in the SW iberian massif: The Ossa-Morena/central iberian contact, Tectonophysics, 332, 295-308, https://doi.org/10.1016/S00401951(00)00262-6, 2001.

Simancas, J. F., Carbonell, R., González Lodeiro, F., Pérez-Estaún, A., Juhlin, C., Ayarza, P., Kashubin, A., Azor, A., Martínez Poyatos, D., Almodóvar, G. R., Pascual, E., Sáez, R., and Expósito, I.: Crustal structure of the transpressional Variscan orogen of SW Iberia: SW Iberia deep seismic reflection profile (IBERSEIS), Tectonics, 22, 1062, https://doi.org/10.1029/2002TC001479, 2003.

Simancas, J. F., Carbonell, R., Gonzalez Lodeiro, F., Pérez-Estaún, A., Juhlin, C., Ayarza, P., Kashubin, A., Azor, A., Martínez Poyatos, D., Saez, R., Almodovar, G. R., Pascual, E., Flecha, I., and Marti, D.: Transpressional collision tectonics and mantle plume dynamics: the Variscides of southwestern Iberia, Geol. Soc. Lond. Mem., 32, 345-354, 2006.

Simancas, J. F., Ayarza, P., Azor, A., Carbonell, R., Martínez Poyatos, D., Pérez-Estaún, A., and González Lodeiro, F.: A seismic geotraverse across the Iberian Variscides: Orogenic shortening, collisional magmatism, and orocline development, Tectonics, 32, 417-432, https://doi.org/10.1002/tect.20035, 2013.

Snelson, C. M., Randy Keller, G., Miller, K. C., Rumpel, H. M., and Prodehl, C.: Regional Crustal Structure Derived from the CDROM 99 Seismic Refraction/Wide-Angle Reflection Profile: The Lower Crust and Upper Mantle, in The Rocky Mountain Region: An Evolving Lithosphere: Tectonics, Geochem. Geophys., 154, 271-291, https://doi.org/10.1029/154GM21, 2013.

Spear, F. S.: Metamorphic Phase Equilibria and pressuretemperature-time paths, Monograph, Mineralogical Society of America, Chelsea, 1993.

Stille, H.: Grundfragen der Vergleichenden. Tectonik, Gebrueder Borntragen, Berlin, 1924.

Taner, M. T. and Sheriff, R. E.: Application of Amplitude, Frequency, and Other Attributes to Stratigraphic and Hydrocarbon Determination, in: AAPG Memoir, Seismic Stratigraphy, Applications to Hydrocarbon Exploration, 26, 301-327, 1977.

Teixell, A., Labaume, P., Ayarza, P., Espurt, N., de Saint Blanquat, M., and Lagabrielle, Y.: Crustal structure and evolution of the Pyrenean-Cantabrian belt: A review and new interpretations 
from recent concepts and data, Tectonophysics, 724/725, 146170, https://doi.org/10.1016/j.tecto.2018.01.009, 2018.

Truyols, J., Arbizu, M., Garcia-Alcalde, J. L., Garcia-López, S., Mendez-Bendia, I., Soto, F., and Truyols, M.: The AsturianLeonese Domain (Cantabrian Zone), in: Pre-Mesozoic Geology of Iberia, edited by: Dallmeyer, R. D. and Martínez García, E., Springer-Verlag, 10-19, 1990.

Villaseca, C., Orejana, D., and Belousova, E. A.: Recycled metaigneous crustal sources for S- and I-type Variscan granitoids from the Spanish Central System batholith: Constraints from Hf isotope zircon composition, Lithos, 153, 84-93, https://doi.org/10.1016/j.lithos.2012.03.024, 2012.
Wever, T.: The Conrad discontinuity and the top of the reflective lower crust-do they coincide?, Tectonophysics, 157, 39-58, https://doi.org/10.1016/0040-1951(89)90339-9, 1989.

Xiaobo, H. and Tae Kyung, H.: Evidence for strong ground motion by waves refracted from the Conrad discontinuity, Bull. Seismol. Soc. Am., 100, 1370-1374, https://doi.org/10.1785/0120090159, 2010. 